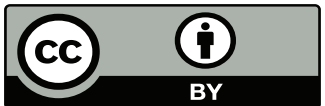

Pieta Hyvärinen ${ }^{a}$

\title{
Sienestystä pohjoisilla puupelloilla: metsien moninaiset taloudet ja plantaasiosentrismin ongelma
}

\begin{abstract}
Mushroom-foraging on northern tree plantations: diverse forest economies and the problem of plantationocentrism

Mushroom-foraging in Finland is often done in forests that live according to a cycle of clearing, planting and thinning. In this article, forest management that prioritizes short-rotation timber production is termed 'plantationocentric', following critiques of capitalocentrism in feminist economic geography. In plantationocentric discourses and practices, plantations, characterized by simplification, forced multispecies labour and temporal disturbances, are taken as the model for all primary production. This in turn subordinates various actual and potential livelihood practices, including foraging. The problem of plantationocentrism is approached through a postcapitalist methodology by examining mushroom-foraging as an intentional form of livelihood production, and by analysing its situated entanglement with plantation-like production. In addition to material subsistence, mushroom-foraging produces well-being and meaningful relationships between people but also species. Therefore, foraging opens up possibilities to see forest economies as more diverse than timber production, and calls into question those economies' anthropocentrism. Plantations are indeed an inseparable part of contemporary mushroom-foraging as well as the conceptualization of diverse forest economies. Nevertheless, adjusting to or acknowledging the presence of plantations does not necessarily mean complying with plantationocentrism. Possibilities for livelihoods amid but also beyond the ruins of plantation economies are sustained in the diversity of forest-based production, and through their critical and affirmative examination.
\end{abstract}

Keywords: diverse economies, foraging, plantationocentrism, silviculture

\section{Johdanto}

Metsien poliittista taloutta Suomessa kiteyttää usein toistettu vaikeus "näbdä metsä puilta" (esim. Lähde 2016; Säynäjäkangas 2019). Puuntuotanto ohjaa metsänhoitoa ja määrittelee metsien käyttöä vahvalla otteella: 1800-luvulta tähän päivään metsäpolitiikan tavoitteena on ollut turvata puu- ja sittemmin myös paperiteollisuuden raaka-aineiden saatavuus ja kasvattaa siten valtion tuloja. Vaikka metsäsektorin toiminta ja toimintaympäristö

${ }^{a}$ Yhteiskuntatieteiden tiedekunta, Tampereen yliopisto, pieta.hyvarinen@tuni.fi 
ovat aikojen saatossa muuttuneet, muutokset voidaan lukea pikemminkin lisäyksiksi puuntuotantokeskeiseen malliin kuin varsinaisiksi paradigmanmuutoksiksi. (Kotilainen \& Rytteri 2011) Myös suomalaisessa mediassa puuntuotantoon keskittyvä, hyötyä ja tehokkuutta korostava diskurssi on edelleen vahvempi kuin luonnonsuojelua, metsien virkistyskäyttöä tai luonnontuotteiden keräilyä korostavat diskurssit (Takala ym. 2019). Viime vuosikymmeninä puuntuotantodiskurssi on tosin muuttunut tavoitteiltaan moninaisemmaksi, kun vastakkainasettelua metsän eri käyttötapojen ja merkitysten välillä on pyritty häivyttämään luomalla mielikuvaa näiden ristiriidattomasta rinnakkaiselosta (emt.; Kröger \& Raitio 2017). Ympäristö- ja kestävyyspuhe ei ole kuitenkaan toistaiseksi horjuttanut puuntuotannon asemaa, vaan esimerkiksi biotalousretoriikan varjolla käynnissä arvioidaan pikemminkin olevan siirtymän entistä nopeakiertoisempaan kuitupuun tuotantoon (Säynäjäkangas \& Kellokumpu 2020).

Suomalaisessa metsäpolitiikassa metsäteollisuuden näkökulma ei siis ole vain yksi muiden joukossa, vaan kulttuurisesti ensisijaistettu suhteessa esimerkiksi marjastajan, sienestäjän, kolopesijän tai harsosammalen näkökulmaan, joista havainnoituna metsät merkityksellistyisivät varsin eri tavoin. Tässä artikkelissa tartun tähän ensisijaistamisen ongelmaan tarkastelemalla sienestyksen ja siinä muotoutuvien monilajisten toimeentulon käytäntöjen kautta tapoja ymmärtää ja tehdä toisin metsiin paikantuvaa alkutuotantoa. Tutkimus asemoituu poliittisen talouden ja poliittisen ekologian kentille, missä sienten ja muiden luonnontuotteiden keräilyä on aiemmin tarkasteltu esimerkiksi nykyaikaisen metsänhoidon paradigmoja kritisoiden (Barron 2015), kehityskeskeistä ajattelua haastaen (Emery \& Pierce 2005) sekä avaten uusia näkökulmia globaaleihin tuotantoketjuihin ja niiden ei-inhimillisiin toimijoihin (Tsing 2015).

Poliittisen talouden lähestymistavat ohjaavat kiinnittämään huomiota siihen, miten puuntuotantokeskeinen ymmärrys metsästä perustellaan taloudellisena. Esimerkiksi Metsätieteellisen aikakauskirjan pääkirjoituksessa vuodelta 2008 tarkastellaan metsien muuta kuin puuntuotannollista käyttöä ja todetaan:

"Kuitenkin näiden käyttömuotojen kehittyminen kansantalouden mittakaavassa yksityismetsätalouden liiketulon korvaajaksi tai merkittäväksi täydentäjäksi on nykylähtökobdilla saavuttamattomissa, koska metsien punntuotannollinen käyttö ja muи käyttö ovat taloudellisesti nïn eri suuruusluokan toimintoja." (Korpilahti 2008, 254)

(Kansan)talous osoittaa sitaatissa tarkastelun mittakaavaa, mutta se on samalla sen laadullinen kehys. Metsien käytön kehystäminen tarkemmin määrittelemättömällä ja siten hegemonisen ymmärryksen mukaisella taloudella kantaa mukanaan valtavaa ontoepistemologista taakkaa: se mahdollistaa tiettyjä tulkintoja, käytäntöjä ja politiikkoja ja tekee mahdottomaksi toisia. Näihin mahdollistamisiin ja mahdottomaksi tekemisiin perustuu talouspuheen ja taloutta koskevan tiedon performatiivinen eli todellisuutta järjestävä politiikka (ks. Callon 1998; MacKenzie ym. 2007).

Performatiivinen politiikka toimii sitä tehokkaammin, mitä näkymättömämpää se on. Feministisen talousmaantieteen piirissä valtavirtaisen talouspuheen itsestäänselvyyksiä ja sen mukanaan kantamia oletuksia, arvotuksia ja normeja on tuotu näkyviin ja purettu J.K. Gibson-Grahamin uraauurtavassa marxilaisen talousmaantieteen feministisessä kritiikissä (2006a) ja siihen pohjautuvassa postkapitalistisen talouden mahdollisuuksien tarkastelussa (2006b), sekä yhä laajenevan moninaisten talouksien lähestymistavan ja tutkimusverkoston piirissä (ks. Gibson-Graham \& Dombroski 2020). Talouden tietämisen ja tekemisen tapojen dekonstruktion ja erilaisten talouden muotojen, käytäntöjen ja suhteiden esiintuomisen kautta verkoston tutkimus, toimintatutkimus ja käytännön toiminta purkavat talouden vaihtoehdottomuuden illuusiota, jota yllä oleva sitaatti metsätalouden osalta edustaa.

Lähestymistavan keskeisimpiä teoreettisia työkaluja on kapitalosentrismin käsite, joka viittaa talouden materiaalis-semioottiseen järjestymiseen kaksinapaisena ja hierarkkisena 
rakenteena kapitalistisia toimintoja, toimijoita sekä toiminnan tiloja ja tapoja ensisijaistaen. Ei-kapitalistiset talouden muodot ovat tällöin olemassa ja ymmärrettävissä vain suhteessa kapitalismiin sen sijaan, että ne näyttäytyisivät monimuotoisina ja omaehtoisina nykyhetken ja tulevaisuuden toimeentulon järjestymisen tapoina. Kapitalosentrismi näkyy esimerkiksi kapitalismia historiallisesti edeltävien tuotannon muotojen määrittelyissä esikapitalistisiksi, hoiva- ja kotityön ymmärtämisessä kapitalistista tuotantoa tukevaksi, sekä kapitalismin laajenemisen ja taloudellisen kehityksen samastamisena (GibsonGraham 2006a, 6-9, 41-42).

Vastaavasti luonnontuotteiden keräilyn marginalisointi voidaan ymmärtää kapitalosentrismin ilmentymänä. Enemmistömaailman ${ }^{1}$ kontekstissa keräily ja muu luontaistalous kuten pienviljely ja kotitarvemetsästys tai -kalastus nähdään tyypillisesti alkupään askelmana taloudellisen kehityksen tikapuilla (ks. Gibson-Graham 2006a, 114-117). Pitkälle teollistuneissa vähemmistömaailman maissa keräilyä taas ei ole totuttu tarkastelemaan nykypäivän olemassa olevana toimeentulon muotona, vaan se ymmärretään esimerkiksi vapaaajan virkistystoiminnaksi ja siten talouden ja tuotannollisen toiminnan ulkopuoliseksi tai sitä tukevaksi (ks. Emery \& Pierce 2005). Suomessakin Tilastokeskus seuraa kotitarvemarjastukseen ja -sienestykseen osallistumista vapaa-ajan käyttöä koskevassa tilastossa (SVT 2020); toisaalta Suomessa seurataan kuitenkin luonnonmarjojen ja -sienten kauppaan tulevia määriä, toisin kuin monessa muussa Euroopan maassa (Turtiainen ym. 2012, 578; ks. Ruokavirasto 2019). Keräilyllä on siis suomalaisessa kontekstissa myös tunnistettu taloudellinen ulottuvuus, joka kuitenkin rajautuu kapitalosentrisesti sen markkinaorientaation mukaan.

Tarkentaakseni nimenomaan alkutuotannon järjestymiseen ja siihen liittyviin, etenkin ei-inhimillistä luontoa koskeviin erityiskysymyksiin kehitän tässä artikkelissa kapitalosentrismiin kytkeytyvää plantaasiosentrismin käsitettä. Plantaasiosentrismillä kuvaan (maa- ja) metsätalouden järjestymistä kapitalistisia tuotantoketjuja tehokkaasti ruokkivia plantaasimaisia tuotannon tapoja ensisijaistavana. Kapitalosentrismin tavoin plantaasiosentrismi on performatiivinen prosessi, jolla on materiaalisia ja poliittisia vaikutuksia: plantaasiosentrismi tuottaa plantaasimaiset käytännöt, toimijat ja tilat todellisemmiksi, keskeisemmiksi ja määrittävimmiksi kuin muut (ks. Alhojärvi 2020, 290). Käsite auttaa ymmärtämään maa- ja metsätalouksien hegemonista järjestymistä plantaaseina ja niiden vaihtoehtoina, plantaasimaista tuotantoa sekä siihen liittyvä yhteiskunnallisia mutta myös lajien välisiä suhteita ensisijaistaen. Plantaasiosentrismin purkamiseksi toteutan talouden moninaisuuden esiin nostamista varten kehitettyä erojen lukemisen strategiaa, jolloin lähestyn metsiin paikantuvaa alkutuotantoa lähtökohtaisesti moninaisena, tilanteisesti muotoutuvana ja erilaisten risteävien ja ristiriitaistenkin järjestysten määrittelemänä (Gibson-Graham 2008, 2014), kuitenkaan unohtamatta plantaasiosentrismin käsitteellistämiseen liittyviä hankaluuksia (ks. Alhojärvi 2020). Avaan plantaasimaisen tuotannon problematiikkaa ja tutkimuksen teoreettis-metodologista lähestymistapaa seuraavassa kahdessa luvussa.

Sienestyksen ja laajemmin keräilyn kautta kysyn, miten metsiin paikantuvaa alkutuotantoa voi ymmärtää toisin kuin plantaasiosentrisesti. Tutkimus perustuu kävelyhaastatteluaineistoon, jonka esittelen yhdessä aineistonkeruun ja laadullisen analyysin menetelmien kanssa neljännessä luvussa. Ensimmäisessä analyysiluvussa tarkastelen sienestystä esimerkkinä metsien alkutuotannon moninaisuudesta kysymällä, miten sienestykesessä tuotetaan toimeentuloa ja hyvinvointia. Luvun lopussa laajennan tarkastelua ja talouden merkityskenttää inhimillisestä toimeentulosta sienestyksen monilajisiin elämää ylläpitäviin verkostoihin. Toisessa analyysiluvussa tarkastelen plantaasimaisuutta ja plantaasiosentrismiä edellä kuvailemieni sienestyksen talouksien muotoutumisessa läsnäolevina hankaluuksina. Erityisesti hakkuuaukioille paikantuvaan korvasienestykseen keskittyen kysyn, miten sienestys ja plantaasit tuotannon tapoina muotoutuvat materiaalis-semioottisessa vuorovaikutuksessa. Lopuksi

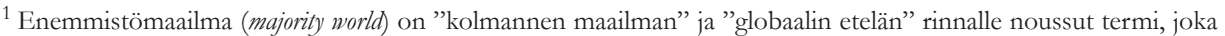
määrittelee maailman historiallisesti heikennettyjä alueita niiden suhteellisen väestömäärän mukaan, kiinnittäen huomion poliittisen ja taloudellisen vallan epäsuhtaiseen jakaantumiseen (Alam 2008).
} 
kokoan yhteen analyysin huomioita moninaisten, ei-plantaasiosentristen metsätalouksien mahdollisuuksista ja tarkastelen niitä sekä niiden käsitteellistämistä tilanteisena ja ristiriitaisena ratkaisuna plantaasiosentrismin ongelmaan.

\section{Plantaasien taloudet}

Sanakirjamääritelmissä plantaasi on maatila, jossa viljellään myyntiin tai vientiin tarkoitettuja kasveja laajoissa monokulttuureissa, usein heikosti koulutetun tai kouluttamattoman työvoiman avulla (Waskey 2011; Encyclopaedia Britannica 2017). Eri lähteiden mukaan plantaaseille on tyypillistä lisäksi esimerkiksi työn kollektiivisuus ja keskusjohtoinen organisaatio, voitontavoittelu, pääomaintensiivisyys ja pakotettu tai tehdasmainen työ (Pryor 1982, 289-291). Monet näistä märitelmistä kumpuavat plantaasien kolonialismiin ja orjuuteen kytkeytyvästä historiasta. 1500-luvulta 1800-luvun loppupuolelle plantaasit olivat keskeinen kolonialistinen instituutio, joka mahdollisti uusien luonnonvarojen hyödyntämisen, ja joka perustui orjatyövoiman käyttöön (Thompson 2010). Kolonialismin hiipuminen ja laajamittaisen orjakaupan päättyminen eivät kuitenkaan lopettaneet plantaaseja, vaan plantaasien leviäminen ja työ plantaaseilla jatkuvat moninaisissa postkolonialistisissa konteksteissa (ks. Pryor 1982; Waskey 2011).

Historiallisia plantaaseja on tarkasteltu esikapitalistisena tuotantona tai mallina kapitalistiselle tuotantotavalle: esimerkiksi Miltz $(1986,47)$ märittelee plantaasin tehtaan ja pellon yhdistelmäksi (ks. myös Thompson 2010). Tämä kapitalosentrinen tulkinta plantaasimaisesta tuotannosta kiinnittää huomion tuotannon kurinalaisuuteen, ihmistyön organisointiin vaihdettaviin yksiköihin, työn tarkkaan aikatauluttamiseen, tuotannon ja kulutuksen erottamiseen toisistaan sekä työläisen erottamiseen työvälineistä (Miltz 1986, 51-52). Haraway ja kollegat (2015) sekä Haraway ja Tsing (2019) laajentavat näitä määritelmiä tarkastelemalla plantaaseja myös ei-inhimillisten toimijoiden näkökulmista. He nostavat esiin kasvien, eläinten ja ihmisten tekemisen plantaasituotannon resursseiksi abstrahoimalla ja vieraannuttamalla (Haraway ym. 2015, 22), sekä kurinalaistamalla paitsi ihmiset, myös muut tuotantoon osallistuvat toimijat (Haraway \& Tsing 2019, 6). Samansuuntaisesti Escobar $(2008,81)$ kiinnittää huomion metsien, jokien, maatilojen ja yhteisöjen verkostojen väkivaltaiseenkin yksinkertaistamiseen ja hierarkkiseen järjestämiseen plantaasitalouksissa. Postantroposentrisestä näkökulmasta plantaasi tuotantomuotona ei siis perustu vain inhimillisen työn järjestämiseen, vaan monilajiseen pakotettuun työhön (Haraway \& Tsing 2019, 5). Pakotettu työ vähentää sen tekijän vapautta tehdä muuta kuin vaadittua työtä sekä vapautta päättää elämäntavastaan, määrittelee Haraway (emt. 7-8) ja toteaa: "JJos työvoima voi paeta, se pakenee plantaaseilta" (emt. 5). Tämä viittaa tulkintani mukaan paitsi plantaaseilla työskentelevien ihmisten vaihtoehdottomuuksiin, myös esimerkiksi luonnonpölyttäjien (Potts ym. 2010) ja maan mikro-organismien vähenemiseen (Pagano \& Dhar 2016) plantaasimaisessa maanviljelyssä sekä niiden korvaamiseen kurinalaisemmin työskentelevillä tarhamehiläisillä ja teollisilla lannoitteilla.

Toinen plantaasimaista tuotantoa sekä ihmisten että ei-inhimillisten toimijoiden kannalta määrittelevä tekijä on Harawayn ja Tsingin (2019, 5-6, 8-11) mukaan sen tuottamat ajalliset katkokset ylisukupolvisessa paikkoihin kiinnittymisessä. Plantaasijärjestelmä perustuu tuottavien yksiköiden - kasvien, eläinten, mikrobien ja ihmisten - siirtämiseen paikasta toiseen (Haraway ym. 2015, 22-23), jolloin sukupolvien ajan paikantunut geeniperimä, eliöyhteisöt ja lajit korvataan toisilla tuottavuuden ja voitontavoittelun nimissä (Haraway 2015, 100). Ymmärrän tällaiset katkokset yhtenä muotona Tsingin (2015, 160-161) kuvailemista ympäristöolosuhteissa muutosta tuottavista häiriöistä (disturbances). Häiriö ei ole Tsingille haitan synonyymi, vaan häiriön haitallisuus määrittyy sen mittakaavan ja sitä seuraavien sommitelmien uusiutumisen mukaan. Häiriöt merkityksellistyvät eri tavoin riippuen siitä, miten niissä osalliset ovat paikantuneet, ja eri näkökulmista tarkastellen ne

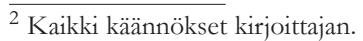


voivat sekä uudistaa että tuhota elinympäristöjä (emts.). Plantaaseillakin ajalliset katkokset mahdollistavat tietynlaisia toimeentulon tapoja samalla kun väkivaltaisesti tekevät mahdottomaksi toisia.

Suomen alueen metsissä plantaasimainen tuotantotapa on vallannut alaa 1950-luvulta lähtien fossiilisten polttoaineiden lisääntyneestä käytöstä seuranneen metsätalouden koneellistumisen ja ammattimaistumisen myötä. 1900-luvun alkupuoliskolla metsistä kaadettiin pääosin vanhimpia ja suurimpia puita, millä ei ollut merkittävää vaikutusta metsän rakenteeseen: häiriö pysyi pienenä ja sommitelma pääosin entisenlaisena. Toisen maailmansodan jälkeen siirryttiin avohakkuisiin perustuvaan metsänhoitoon, josta nykyään käytetään nimitystä jaksollinen kasvatus (Äijälä ym. 2019, 34). Jaksollisesti kasvatettu metsä on saman ikäistä ja lajistoltaan yksipuolista. Kasvatusvaihe päättyy uudistuseli päätehakkuuseen, jossa alueelta poistetaan kaikki tai lähes kaikki puut suhteellisen nuoressa 60-100 vuoden iässä. Hakkuun jälkeen seuraava puusukupolvi kylvetään, istutetaan tai sen annetaan kylväytyä pystyyn jätetyistä siemenpuista. (Ks. Saksa ym. 2014) Jaksollinen kasvatus on vuoden 2014 metsälain uudistuksen jälkeen saanut rinnalleen poimintahakkuisiin perustuvan jatkuvan kasvatuksen mallin, mutta suurinta osaa Suomen alueen metsistä hoidetaan edelleen edellä kuvattujen periaatteiden mukaisesti (Metsäkeskus 2018). Luonnontilaista, puuntuotannon ulkopuolista metsää on eri määritelmien mukaan alle prosentti Suomen metsäalueista (FAO 2020a, 17) tai vajaa kolme prosenttia koko maan pinta-alasta (Sabatini ym. 2018, 1432).

Jaksollisen kasvatuksen mukaisesti hoidetuista metsistä käytetään toisinaan kritisoiden nimitystä puupelto. Nimitys hävittää metsän semanttisesti ja alleviivaa tuotantotavan yhtymäkohtia maatalouteen ${ }^{3}$. Punplantaaseista Suomessa puhutaan kuitenkin lähinnä trooppisiin puuviljelmiin viitaten (ks. esim. YLE 2016), kun taas englanninkielisissä metsäkeskusteluissa esimerkiksi YK:n elintarvike- ja maatalousjärjestö FAO:n piirissä käsite plantation on eri muodoissaan vakiintunut viittaamaan tuotantokäyttöön istutettuihin, hoidettuihin sekä lajistollisesti ja ikäjakaumaltaan yksipuolisiin metsiin riippumatta niiden kasvuvyöhykkeestä (Ks. FAO 2020b, 5). Pesäeron tekeminen plantaaseihin ei vaikuta olevan vain kielikysymys: FAO:n metsäresurssiarvioinnin Suomen-raportissa plantation määritellään instituution käsitteenmäärittelystä poiketen ei-kotoperäisistä lajeista koostuviksi istutusmetsiksi, jolloin niiden laajuus Suomen alueella lasketaan vähäiseksi (FAO 2020a, 15).

Plantaasien problematiikkojen etäännyttäminen suomalaisesta kontekstista on joiltain osin perusteltua: esimerkiksi inhimillisen työn organisointi suomalaisessa metsätaloudessa eroaa merkittävästi etenkin historiallisista mutta myös monista nykypäivän plantaaseista. Samoin Suomen alueen metsien yksityisille, yhteisöille ja valtiolle pirstaloitunut omistusrakenne poikkeaa trooppisten maa- ja metsäalueiden omistuksesta, joka on tyypillisesti keskittynyttä ja kantaa usein kolonialismin perintöä (ks. esim. Escobar 2008). Lähemmässä tarkastelussa nämä eronteot alkavat kuitenkin häilyä. Metsälainsäädännön velvoittavuudessa etenkin ennen 1990-lukua on piirteitä työn organisoinnin hierarkkisuudesta ja ylhäältä sanellusta aikatauluttamisesta (ks. Kasanen \& Heikkinen 2012). Tänä päivänä työ puuntuotannon parissa järjestyy muun plantaasityön tavoin osaksi globaaleja tuotantoketjuja, joissa tuotanto ja kulutus eriytyvät kauas toisistaan ja jotka mahdollistavat yksityisten voittojen kasaantumisen (ks. Kekkonen 2011). Myös siirtotyön osuus puuntuotannossa vaikuttaa olevan lisääntymässä (ks. YLE 2020). Lisäksi maan haltuunottoon ja omistukseen on Saamenmaan alueella nähty liittyvän kolonialistisia piirteitä, mikä on värittänyt metsien käyttöön liittyviä konflikteja Ylä-Lapissa (Jokinen 2019, 60; ks. myös Kuokkanen 2020).

Tätäkin selkeämmin puuntuotannon plantaasimaisuus ilmenee, kun metsiä tarkastellaan monilajisina kokonaisuuksina. Metsän plantaasimaistaminen abstrahoimalla sen monimutkaiset eliöyhteisöt yhteismitalliseksi, hyödynnettäväksi resurssiksi (ks. Haraway ym. 2015; Säynäjäkangas 2019) on pääomavaltaisen metsäteollisuuden etujen

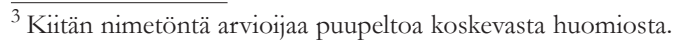


mukaista. Metsään resurssina kytkeytyy odotuksia rahallisista tuotoista, joiden realisoinnin mahdollisuudet määräytyvät puunjalostusteollisuuden globaaleilla markkinoilla. Tällä hetkellä erityisesti nopeakiertoinen kuitupuun tuotanto ohjaa kiihdyttämään metsien ajallisia rytmejä sekä syrjäyttämään puuntuotannolle merkityksettömiä lajeja tavoilla, joita voi monien ei-inhimillisten eliöiden kannalta pitää väkivaltaisina ja peruuttamattomina häiriöinä (ks. Koivula \& Vanha-Majamaa 2020; Säynäjäkangas \& Kellokumpu 2020). Häiriöt ilmenevät metsien ikärakenteen ja lajikirjon yksipuolistumisena, metsäautoteiden halkomina elinympäristöinä ja uhanalaistettujen lajien keskittymisenä sirpaleisille luonnonsuojelualueille. Näin rakentuu plantaasioseenin, plantaasien aikakauden (Haraway ym. 2015) maisema pohjoisella havumetsävyöhykkeellä.

\section{Plantaasiosentrismin purkaminen ja sen hankaluudet}

Tsing toteaa, että maataloudessa plantaasimainen tuotanto on niin pitkälle normalisoitunutta, että plantaasi on alkanut täyttää maanviljelyn käsitteen merkitystä (Haraway \& Tsing 2019, 6). Vastaavasti plantaasimaisen tuotannon aikaansaamia häiriöitä Suomen alueen metsissä voi olla vaikea tunnistaa, sillä ne ovat luonnollistuneet osaksi jaettua kansallista metsäkuvastoa. Plantaasiosentrismi ilmenee metsätaloudessa paitsi puuntuotannon ja metsänhoidon näkyvinä käytäntöinä ja niitä tukevina politiikkoina, myös toisenlaisten metsiin paikantuvien toimeentulon ja tuotannon tapojen tunnistamattomuuksina, ulossulkemisina ja marginalisointeina (ks. Gibson-Graham 2006a). Plantaasiosentrisessä metsätaloudessa metsän lajistollinen monimuotoisuus, pitkät ajalliset jatkumot sekä monilajisen työn omaehtoisuus tai hitaus merkitsevät joko epätarkoituksenmukaista ja tuottamatonta tai kaiken tuotannon ulkopuolista, muistomerkin tapaan säilytettyä metsää. Muun metsään paikantuvan tuotannon toiseuttaminen taas tulee näkyviin esimerkiksi keräilytuotteiden nimeämisessä metsien sivutuotteiksi (Juutinen 2011, 3) tai ei-puuaineksisiksi tuotteiksi (Luonnonvarakeskus 2016), joka vastaa englanninkielisiä puuntuotantoa ensisijaistavia termejä kuten non-timber forest products (Barron 2015, 176).

Tekemällä plantaasimaisista käytännöistä ja ymmärryksistä itsestäänselvyyksiä plantaasiosentrismi epäpolitisoi alkutuotantoa koskevaa päätöksentekoa ja köyhdyttää yhteiskunnallista mielikuvitusta sen tulevaisuuksien suhteen (ks. Gibson-Graham 2006a, 7-9; Gibson-Graham 2006b, xxviii). Gibson-Graham (2006a) lähestyy kapitalosentrismin vastaavaa eettis-poliittista problematiikkaa dekonstruktion kautta: sekä kapitalismia että sen "toisia" tarkastellaan lähtökohtaisesti moninaisina ja muuttuvina, vailla kiinteää ydintä. Tällöin talous ei järjesty ennalta määrättyjen ydinkategorioiden ympärille, vaan on avoin ja tilanteisesti muotoutuva toimeentulon ja hyvinvoinnin suhteiden, käytäntöjen ja neuvottelujen kenttä. Vastaava antiessentialistinen näkökulma plantaaseihin tarkoittaa ei-plantaasimaisen tuotannon moninaisuuden esiintuomista sekä plantaasien tarkastelua sisäisesti moninaisina ja ristiriitaisinakin. Dekonstruktion metodologiseksi ja ontoepistemologiseksi välineeksi Gibson-Graham (2006b, xxxi-xxxii; 2008) ehdottaa erojen lukemisen (reading for difference) strategiaa, jossa tuodaan näkyväksi erilaisia tapoja tehdä, ymmärtää ja järjestää taloutta. Eroja lukemalla on tuotu esiin talouden historiallista ja nykyistä moninaisuutta ja avattu suuntia sen uudenlaisille tulevaisuuksille (ks. esim. Roelvink ym. 2015).

Talouden moninaisuutta on alkujaan luettu ihmiskeskeisesti, mutta posthumanismin ja poliittisen ekologian siivittämänä tutkimuskentällä on viime vuosina nostettu esiin ja teoretisoitu myös ei-inhimillistä toimijuutta talouksien osana (ks. esim. Barron 2015; Roelvink 2015; Miller 2019). Ihmisen syrjäyttäminen talouden keskiöstä on kuitenkin haastavaa. Miller (2020) ehdottaa osittaisena vastauksena ongelmaan huomion siirtämistä inhimillisestä toimeentulosta ja siihen osallistuvista ei-inhimillisistä toisista siihen, miten ihmiset ovat osa monilajisia elämää ylläpitäviä verkostoja. Tällöin talouden ja ekologian väliset erot hämärtyvät: Gibson-Grahamin ja Millerin (2015, 
8) mukaan talous ekologiana muodostuu monimutkaisesta eettisten ja energeettisten keskinäisriippuvuuksien virrasta.

Alkutuotannossa ei-inhimillistä toimijuutta ja toimijuuden verkostomaisuutta painottava näkökulma on erityisen paikallaan, sillä maa- ja metsätalouksissa ei-inhimilliset toiset ovat lähtökohtaisesti läsnä eri tavoin elävinä, tuottavina tai plantaasimaisesti resursseiksi tuotettuina. Moninaisen talouden lähestymistapa houkutteleekin ajattelemaan myös alkutuotannon lajien välistä vuorovaikutusta toisin: sen sijaan, että metsätalous nähdään metsään kohdistuvina toimintoina tai taloutena, jonka toiminnan ala on metsä, se voisi olla prosesseja, joissa monilajiset yhteisöt neuvottelevat metsäelämän yhteisiä bio- ja geososiaalisia ulottuvuuksia (ks. Miller 2020, 407). Erojen lukeminen maa- ja metsätalouksien käytännöistä voi siis paitsi avata mahdollisuuksia ymmärtää tuotantoa toisin, myös siirtää sijoiltaan plantaasiosentrismin ibmiskeskeistä hegemoniaa.

Erojen lukeminen on luonteeltaan affirmatiivista eli mahdollisuuksia avaavaa ja toivoa herättävää (Gibson-Graham 2006b, 2008, 2014). Talouden kapitalistiset ulottuvuudet ovat luennassa läsnä, mutta eivät yksin määrää niiden merkityksiä (Gibson-Graham 2014, 149-151). Myös alkutuotannon eroja lukiessa plantaasit ovat mukana muovaamassa tuotannon käytäntöjä, paikkoja, tuotantoketjuja sekä niitä koskevia ymmärryksiä, mutta eivät plantaasiosentrismin mukaisina totaliteetteina, vaan yhtenä määreenä loputtoman monimutkaisissa ylimääräytyneissä suhteissa, joissa "jokainen tila ja prosessi on muotoutunut kaikkien muiden risteyksessä" (Gibson-Graham 2006b, xxx). Erojen lukeminen kytkeytyy Sedgwickin (2003) hahmottelemaan reparatiiviseen lähestymistapaan, jossa keskeistä on avoimuus tulevaisuuden ennalta-arvaamattomuudelle (ks. Gibson-Graham 2008). Reparatiivisesta positiosta maailmaa ei pyritä hallitsemaan tai selittämään kaikenkattavilla teorioilla tai käsitteillä, vaan pyrkimyksenä on kehittää kykyä tulla toimeen sen kanssa pysyttelemällä avoimena yllätyksille (Sedgwick 2003).

Yksioikoisesti toteutettu siirtymä kapitalo- tai plantaasiosentrismin kritiikistä moninaisuuden vahvistamiseen saattaa kuitenkin jättää huomiotta käsillä olevan ongelman sitkeyden. Reparatiiviselle lähestymistavalle rinnakkaisia paranoideja tiedontuotannon käytäntöjä hyödyntäen Alhojärvi (2020) muistuttaa, että kapitalosentrismin käsittäminen tai esittäminen rajattuna, ratkaistuna tai etäännytettynä ongelmana ja keskittyminen talouksien ei-kapitalistiseen moninaisuuteen ilman niiden kapitalististen ulottuvuuksien analyysiä saattaa pikemminkin vahvistaa kuin purkaa kapitalosentrismiä. Vastaavasti alkutuotannossa paranoidi lähestymistapa ohjaa epäilemään plantaasimaisuuden läsnäoloa mitä erilaisimmissa ympäristöissä ja tilanteissa sekä paljastamaan sen kaikkialla väistämättömän samansuuntaisia merkityksiä (ks. Sedgwick 2003 130-138, 141-145). Vaikka paranoidit tietämisen tavat pelkistävät ilmiöiden moninaisuutta plantaasiosentrismin kaltaisiin laaja-alaisiin käsitteisiin nojautuen ja siten rajaavat tulkinnan ja toiminnan mahdollisuuksia, kyse ei Sedgwickin mukaan ole oikeista ja vääristä vaan eri tavoin käyttökelpoisista episteemisistä käytännöistä: "Paranoia tietää joitakin asioita byvin ja toisia buonosti’" (emt. 130).

Paranoidi lähestymistapa muistuttaa, että plantaasiosentrismille ei voi alkutuotannon moninaisuuden avautumisen myötä kääntää selkäänsä, vaan sen läpitunkevuutta ja performatiivisuutta tulisi tarkastella osana tätä moninaisuutta - ja sen tarkastelua. Plantaasien taloudet ja niiden ensisijaistaminen ovat satojen vuosien ajan raunioittaneet sekä ei-inhimillisen luonnon ja sen kanssa toimeen tulemisen tapojen monimuotoisuutta että inhimillisiä kykyjä kuvitella toisenlaista tuotantoa. Eläminen plantaasitalouksien ontoepistemologisilla raunioilla on pikemminkin alkutuotannon moninaisuuden ja sen tarkastelun tosiasiallinen lähtökohta kuin uhkaava, mutta kenties vältettävissä oleva tulevaisuuskuva (ks. Tsing 2015). Plantaasiosentrismiä ei siis tule lähestyä ongelmana, joka on yksinkertaisesti, tai lainkaan, ratkaistavissa, vaan hankaluutena, joka ilmenee eri tavoin erilaisissa suhteissa ja tilanteissa (ks. Haraway 2016; Alhojärvi 2020). Tämä ei tarkoita antiplantaasiosentristen käytäntöjen ja tulkintojen mahdottomuutta, vaan muistuttaa niiden osittaisuudesta sekä 
toimijan ja tulkitsijan hankalasta asemasta yhtä aikaa plantaasiosentrismin tuottamana, tuottajana ja purkajana. Plantaasimaisen tuotannon herkkä ja luova kritiikki edellyttääkin plantaasien ja plantaasiosentrismin monikerroksisen tilanteisuuden tunnistamista.

\section{Aineisto ja menetelmät}

Tutkimuksen empiirinen aineisto muodostuu yhdeksästä kävelyhaastattelusta, jotka tein eri puolilla Suomea keväällä 2018. Kukin nauhoitettu haastattelu oli pituudeltaan kahdesta neljään tuntia, ja litteroitua haastattelumateriaalia kertyi 178 sivua. Haastateltavat täyttivät myös lyhyen verkkolomakkeen, jossa kysyin henkilökohtaisia taustatietoja sekä tietoja sienestyksestä. Tutkimusavustaja otti haastatteluympäristöistä lisäksi noin 500 valokuvaa, jotka muodostavat kuvallisen tausta-aineiston.

Etsin haastateltavia sosiaalisen median sieniryhmästä sekä paikallisten sieniseurojen sähköpostilistoilta, jolloin haastateltaviksi valikoitui innokkaita sienestäjiä ja sieniharrastajia eri puolilta Suomea. Haastateltavien ikäjakauma oli laaja, 27-70 vuotta, ja heistä neljä oli naisia ja viisi miehiä. Kaikki olivat syntyneet ja asuivat vakituisesti Suomessa. Haastateltavista vain yksi oli haastatteluhetkellä palkkatyössä, ja hänkin juuri siirtymässä eläkkeelle. Neljä haastateltavaa oli oman ilmoituksensa mukaan eläkeläisiä ja yksi työkyvyttömyyseläkkeellä, yksi haastateltava oli kuntoutumassa ja yksi aikuisopiskelija. Keräilyn lisäksi kolme haastateltavaa harjoitti metsästystä ja kalastusta, neljä luontovalokuvausta tai sienten bongausta, ja lähes kaikki kertoivat kulkevansa metsässä myös virkistystarkoituksessa esimerkiksi koiran kanssa tai retkeillen. Kaksi haastateltavaa kertoi omistavansa metsää tai osallistuvansa sen hoitoon puuntuotantotarkoituksessa.

Haastattelukutsussa hain haastateltavia nimenomaan korvasienestystä koskevaan tutkimukseen, ja haastattelut toteutettiin touko- ja kesäkuussa, jolloin kotelosieniin kuuluva, poimulakkinen korvasieni (Gyromitra esculenta) on pääasiallinen kerättävä ruokasienilaji. Tästä huolimatta haastateltavat puhuivat sienestyksestä ja muusta keräilystä myös yleisemmin, sekä vaihtelevasti muusta metsässä liikkumisesta ja muunlaisesta omakätisestä ruoantuotannosta. Korvasienet kuitenkin suuntasivat aineistonkeruuta kohti plantaasien tematiikkaa, sillä ne esiintyvät erityisen runsaslukuisina muutaman vuoden ikäisillä hakkuuaukeilla, erityisesti hiekkapohjaisissa entisissä havumetsissä (Korhonen 1990, 245).

Tutkimuksen lähestymistapa on etnografinen, jolloin analyysi perustuu ilmiön tiheään kuvaukseen. Reparatiivisesti suuntautuen lähestyn sienestystä monimerkityksellisenä ja monien määrittelevien tekijöiden risteämissä muotoutuvana sen sijaan, että pyrkimyksenä olisi ilmiön tyhjentävä selittäminen. Kuitenkin erityisesti analyysin jälkimmäisessä osassa yllä esitetty teoreettinen kehys ja plantaasiosentrismin käsite ohjaavat tulkintaa paranoidiin suuntaan. Moniulotteista tiedontuotantoa tavoitellen liikunkin tutkimuksessa edestakaisin reparatiivisten ja paranoidien tietämisen käytäntöjen välillä. Tämä liike saa aikaan analyysin sisäistä kitkaa, joka muistuttaa tiedontuotannon moniaalle suuntautuvasta eettispoliittisesta vastuullisuudesta: paranoidit tietämisen käytännöt, etenkin kohdistuessaan itseensä, muistuttavat tiedon ja käsitteellistysten lähtökohtaisesta epäilyttävyydestä, kun taas reparatiiviset pyrkimykset korostavat tiedon toimivuutta suhteessa ennalta-arvaamattomiin tulevaisuuksiin (ks. Sedgwick 2003).

Käytännössä analyysi eteni haastatteluaineiston aineistolähtöisen teemoittelun ja analyysin myötä kehittyvän käsitteistön vuoropuheluna. Ensin jaottelin aineiston sen käsittelyn helpottamiseksi sienten löytämistä, sienestäjien arkea ja sienestysmaastoja koskeviin osioihin. Sen jälkeen analysoin niistä toimeentulon ja hyvinvoinnin tuotannon moninaisuutta, ristiriitaisuuksia ja eroavaisuuksia. Näin muodostunut paikantunut ja tilanteinen ilmiön kuvaus on keskiössä ensimmäisessä analyysiluvussa. Toisella lukukierroksella plantaasit hahmottuivat etenkin korvasienestyksessä läsnä olevina paikkoina ja tuotannon tapoina, jolloin analyysi limittyi plantaasiosentrismin käsitteen kehittelyyn. Tarkennan huomioni plantaaseihin ja plantaasiosentrismiin toisessa analyysiluvussa. 


\section{Keräilyn moninaiset metsätaloudet}

Suomessa luonnontuotteiden keräily on yleistä: suomalaisista aikuisista $46 \%$ poimii marjoja ja $33 \%$ sieniä (SVT 2020), ja väestötasolla keräilyyn käytetään lähes 25000 henkilötyövuotta eli keskimäärin 9,5 tuntia vuodessa per henkilö (Saastamoinen \& Vaara 2009, 436-437). Keräilyllä on myös vakiintunut kulttuurinen asema: marjasatoennusteet ovat osa valtakunnan uutisvirtaa, keräilyn mahdollistavat jokaisenoikeudet nauttivat laajaa arvostusta (Vuolle \& Oittinen 1994, 25-26), ja itse poimitut marjat ovat lahja- ja vaihtokäytäntöjen kautta osa niidenkin suomalaisten ruokavaliota, jotka eivät itse marjastaa (ks. Ylitalo 2008). Keräilyn yleisyydestä ja vakiintuneisuudesta huolimatta sen merkityksestä osana kotitalouksien toimeentuloa on olemassa vain karkeita kokonaisarvioita: kerättyjen marjojen rahallinen arvo on vähintään 100 miljoonaa ja sienten 50-55 miljoonaa euroa (Vaara ym. 2013, 593). Lisäksi tiedetään, että keräiltyjen tuotteiden määrät vaihtelevat sekä alueittain että kaupungin ja maaseudun välillä merkittävästi. Poimitut marjamäärät ovat suurempia Pohjois- ja Itä-Suomessa ja maaseudulla (Ylitalo 2008; Pouta ym. 2006), mutta sienestyksessä myös eteläsuomalaiset ovat innokkaita (Saastamoinen 2012, 18).

Erot poimintamäärissä viittaavat keräilyn vaihteleviin merkityksiin sen harjoittajille. Haastatteluissa nousikin esiin erilaisia tapoja, joilla sienestys oli osa haastateltavien toimeentuloa. Joillekin sienet olivat lähinnä muiden ruokien lisuke tai mauste, mutta toiset söivät yli sata kiloa sieniä vuosittain. Tällöin sienestys vähentää ostettavan ruoan tarvetta ja muuttaa syötävien ruokien koostumusta:

H1: [T]otta kai se vaikuttaa, et jos mie kerään sieniä vaikka sataviiskyt kiloo nïn ei se mitenkään ole silleen sataviiskyt kiloo enemmän sille sykesylle sitä syömistä [...]

PH: Vaikuttaako se munten sïhen että millaista ruokaa syöt?

H1: Niin, varmasti, et aikea monissa resepteissä mie yleensä korvaan vaikeka lihan sienillä.

Sienten merkitys niiden kerääjien ruokavalioissa oli kuitenkin myös suoraviivaista korvaamista monisyisempää. Joidenkin haastateltavien ruokavalio rakentui pitkälti omakätisen keräilyn, viljelyn ja kalastuksen varaan, ja muutamalle sienestys oli tärkeää nimenomaan osana ruokaomavaraisuuden tavoittelua. Ruokaomavaraisuuden lisääminen on tapa ottaa ruoan tuotantoprosesseja haltuun, jolloin kotitalous merkityksellistyy keskeisenä tuotannon tilana (Morrow \& Dombroski 2015). Keräilyssä tuotanto järjestyy paitsi osana kotiin paikantuvaa arkea, myös muuta luonnossa liikkumista, retkiä ja reissuja, jolloin lähi- ja kaukaisemmatkin metsät tulevat osaksi kotitalouden tuotantotiloja.

Oman kulutuksen lisäksi haastateltavat lahjoittivat sieniä läheisilleen kuten aikuisille lapsille tai ikääntyneille vanhemmille, jolloin sienet toimivat osallisina hoivasuhteissa (ks. Puig de la Bellacasa 2017). Sienillä käytiin myös erilaista vaihtokauppaa naapurustoissa ja tuttujen kesken: eräs haastateltava sai korvasieniä vastaan hirvenlihaa, toinen maksoi sienillä parturikäynnit. Lisäksi lähes kaikki haastateltavat myivät, olivat myyneet tai suunnittelivat myyvänsä sieniä. Tämä poikkeaa keskimääräisestä suomalaisesta sienestäjästä: esimerkiksi vuonna 2011 vain noin prosentti kotitalouksista poimi sieniä kaupallisiin tarkoituksiin (Turtiainen ym. 2012, 574). Useimmat haastateltavat olivat myyneet sieniä satunnaisesti ravintoloihin tai tutuille, mutta eräällä pariskunnalla keräilytuotteiden suoramyyntiverkostot olivat laajat ja vakiintuneet ja myynnistä saadut tulot nousivat vuosittain useisiin tuhansiin euroihin.

H2: [O]liko se viime syksynä vai edellissyksynä kun pankin täti soitti, että teiän rahaliikenne ei toimi [nauraa] teiän rahaliikenteessä ei tapabdu mitään kun pankist ei menny sit enää ku laskut, kun me elettiin oikeestas koko se beinäkunsta lokakunbun asti nïn elettiin koko ajan niillä metsäst tulleilla rahoilla ja sebän on verotonta tuloa ja tuottoa et siitä ei mitään tarvi maksaa. 
Keräilytuotteiden myynti on Suomessa pääosin verotonta (Verohallinto 2020), eikä siihen sisälly pienimuotoisena juuri muutakaan sääntelyä (Lavola 2019), mikä laskee kynnystä myydä ylimääräistä satoa tai poimia myyntitarkoituksessa. Yhdessä vakiintuneiden jokaisenoikeuksien kanssa tämän voi ymmärtää keräilyyn toimeentulon muotona kohdistuvaksi institutionaaliseksi tueksi tai ainakin sille suotuisien olosuhteiden luomiseksi osana pohjoismaisen hyvinvointivaltion järjestysten ja moninaisten talouksien yhteiseloa (Eskelinen ym. 2020, 14-18). Suoremmin keräilytalouksia on Suomessa tuettu ylläpitämällä järjestelmällistä koulutusmallia keruutuotteiden poimijoille (ks. Ristioja 2017, 26), sekä erilaisilla keräilytietoa levittävillä hankkeilla ja oppailla (ks. Salo \& Turtiainen 2015, 183).

Valtaosa haastateltavista oli suorittanut jonkinlaisen sienikurssin, vaikka monet korostivatkin aktiivisen sienestyksen merkitystä sienituntemuksen ja sienipaikkatiedon kannalta olennaisempana (ks. Hyvärinen 2019). Koulutuksen ja paikallistuntemuksen merkitys korostui kolmen haastateltavan osalta, jotka suunnittelivat aloittavansa liiketoimintaa sienten kasvatukseen ja jatkojalostukseen, sieniretkiin ja -kartoituksiin sekä sienten puoliviljelyyn ja sienikursseihin liittyen. Kahdelle heistä ammatillinen uudelleenkouluttautuminen oli avannut mahdollisuuksia siirtyä palkkatyöstä kohti itsenäisempää työelämää; kahdelle sysäyksen siirtymään antoi myös työpaikan yhteistoimintaneuvotteluissa eteen tullut eläkeputki. Sieniin pohjautuva liiketoiminta ja toimeentulo nähtiin lisäksi vaihtoehtona liian kuluttavalle - tai liiallista kulutusta tuottavalle - palkkatyölle:

\section{PH: Voiko kysyä mitä teit aikasemmin? \\ H3: Vaatetusartesaani. Vaateteollisuns on aika abtaalla Suomessa. Ja rätei ja lumpui riittäa [naurabtaa], ei tarvi ommel enää ybtään lisää.}

Huolimatta suuristakin keräilytuloista tai alkavasta liiketoiminnasta haastateltavat olivat haluttomia määrittelemään sienestystä työksi - korkeintaan sienten puhdistus ja käsittely saattoivat toisinaan tuntua työläiltä. Reparatiivisessa hengessä tulkitsen tämän haastateltavien tietoiseksi strategiaksi pitää sienestys työhön liitettyjen tulostavoitteiden ja tehokkuusvaatimusten ulottumattomissa; paranoidimpi tulkinta voisi nojautua kapitalosentrismin tuottamaan palkkatyökeskeiseen ymmärrykseen työstä. Työntekoon liitettiin raskautta, mikä sienestyksestä puuttui: sienestyksen koettiin päinvastoin edesauttavan töistä palautumista ja tarjoavan niille vastapainoa arjessa. Toisaalta palkkatyö myös hankaloitti sienestystä ajankäytöllisesti ja siksi, että työpäivän jälkeen ei välttämättä jaksa enää lähteä sienimetsälle.

\section{H7: JJjos mä bankkisin jonkun sellasen työn, sellaisen palkkatyön mikä ois sellanen, nïn enbän mä oikeen ehtis kerätä noit sienii, tai oikeen kauheesti ehkeä muntakaan, koska jos mä oon vaik siellä rakennuksilla, nïn mä en jaksa tebdä mitään sen päivän jälkeen.}

Kyseinen haastateltava näki osuuskuntapohjaisesti järjestyneen, omaan tahtiin tehtävän keräilyn mahdollisena työn muotona niille, jotka eivät pysty tai suostu "pakkotahtiseen" tuntiperustaiseen palkkatyöhön sen fyysisen tai psyykkisen kuormittavuuden vuoksi. Yhdessä edellä kuvailtujen liiketoimintasuunnitelmien kanssa visio kertoo keräilyn myötä avautuvista tulevaisuuden talouden horisonteista, joissa toimeentulo ja hyvinvointi kietoutuvat lähtökohtaisesti yhteen. Luontaistaloudellisten toimeentulon käytäntöjen onkin todettu lisäävän hyvinvointia esimerkiksi edistämällä fyysistä aktiivisuutta, terveellistä ruokavaliota ja yhteisöllisyyttä (Burnette $y m$. 2018). Haastatteluissakin todettiin sienestyksellä olevan monenlaisia hyvinvointivaikutuksia:

H1: Ja kuitenkin sienestys on mun mielestä ihan tosi antoisa harrastus, et sïnä tulee liikeuntaa ja sitten se on vähän meditatiivistakin, ja sit siinä saa vielä sitä ruokaa hankittua samalla, nïn mun on hankala ymmärtää sitä että miksi siitä ei olis kïnnostunut. 
Liikunnan, mielenterveyden tukemisen ja ruoan hankkimisen lisäksi haastatteluissa nousi esiin sienestyksen hyvinvointia tuottava sosiaalinen ulottuvuus: sieniä poimittiin yhdessä perheen tai ystävien kanssa, niitä lahjoitettiin tai vaihdettiin lähipiirissä, ja lisäksi neljä haastateltavaa toimi aktiivisesti sieniseurassa tai vastaavassa yhteisössä. Sienestys saa siis aikaan ja ylläpitää merkityksellisiä, hyvinvointia tuottavia suhteita (ks. Hirvilammi 2011, 69). Merkitykselliset suhteet eivät muodostu vain ihmisten kesken vaan myös lajien välille: sienestyksessä merkityksellisinä toisina (Haraway 2003) oli läsnä paitsi sieniä, myös kasveja, hyönteisiä sekä selkärankaisia lemmikkikoirista karhuihin, hirviin ja sammakoihin. Muiden lajien merkitys hyvinvoinnille sanallistettiin ensisijaisesti suhteessa sieniin sekä metsiin kokonaisuudessaan:

\section{PH: Mikä se motivoi läbtemään sienimettälle? \\ H9: No ensinnäki tietenki on mukava saada sieniä, se on tietenki se primääri tarkotus. Mutta minä vain tykkään olla täälä, se on se ebkä minulle se tärkeämpi asia, että minä saan kuleskella täälä. Ei tämä aukossa kulukeminen sinänsä oo sen kummempaa, mutta samallahan sitä kulukee muntenki täälä metässä. Metässä kulukeminen on semmosta jotenkin viebättävvää.}

Monilajisesta näkökulmasta tarkasteltuna keräily on muun ruoantuotannon tavoin toimijoiden keskinäistä muotoutumista konkreettisessa ja materiaalisessa mielessä, syötävien sienten kanssa yhteensulautumisena (ks. Bennett 2007; Haraway 2008). Sienestys on myös monilajisia hoivasuhteita, kuten edellä mainittua sienten välittämää ja mahdollistamaa ihmisten välistä huolenpitoa, mutta myös sieniin kohdistuvaa sekä kenties jopa niiden ihmisiin hyvinvointivaikutusten muodossa kohdistamaa hoivaa (ks. Puig de la Bellacasa 2017). Lisäksi sienestys on muiden omakätisen ruoantuotannon muotojen tavoin monilajista, tilanteista tiedontuotantoa (ks. Vehviläinen 2014; Hyvärinen 2017, 2019). Sienestäjien osallistuminen metsien monilajisten talouksien elämää ylläpitäviin verkostoihin (ks. Miller 2020) on siis paitsi toislajisten syömistä, myös hoivasuhteiden affektiivisia kytköksï sekä ei-inhimillisen toimijuuden tunnistavia tietämisen tapoja (ks. myös Poe ym. 2014).

Haastatteluaineistossa erilaiset lajien keskinäisen yhteismuotoutumisen tavat kietoutuvat toisiinsa: syötävien sienten löytäminen perustui herkkään muuttuvan ympäristön havainnointiin ja pitkäjänteiseen, jopa ylisukupolviseen paikkoihin kiinnittymiseen (ks. myös Emery 2001; Kaaronen 2020). Eräs haastateltava kuvaa, miten ei voisi kuvitella poimivansa sieniä myyntitarkoituksiin asuinsijoiltaan pääkaupunkiseudulta, mutta kotiseudulla KeskiSuomessa sienitalous voisikin kukoistaa:

\section{H7: Nïn sitä mä oon miettinyt sitä paik.kasidonnaisuntta, et jos mä täällä jotenkin voin saada rahaa siit sienestämisestä, nïn en mä voi saada Helsingissä, myös sen takia et sïhen matkustamiseen menis lïan pitkä aika. Ja koska mulla ei siellä ole, se on vaan äärimmäisen epätehokasta vaan mennä johonkin random metsään ja yrittää löytää sielt jotain.}

Paikkatieto ei kuitenkaan vielä takaa sienisatoa. Haastattelut tehtiin keväällä 2018, joka oli ennätysmäisen kuiva ja kuuma, ja korvasienisato sen vuoksi huono kautta maan. Korvasienet ovat lyhyen satokautensa takia erityisen herkkiä sääolosuhteiden vaihtelulle, mutta lämpötilat ja sademäärät vaikuttavat kaikkien sienten elämään ja itiöemien muodostumiseen. Ilmaston lämpenemisen myötä muuttuvat sääolosuhteet, lisääntyvät sään ääri-ilmiöt sekä ilmankosteuden ja maaperän koostumuksen muutokset voivat vaikuttaa monimutkaisilla, paikka- ja lajispesifeillä tavoilla sienten esiintyvyyteen (Diez ym. 2013): esimerkiksi kevätsienten on todettu kasvattavan itiöemiä aiempaa aikaisemmin (Kauserud ym. 2010).

Sienestyksen koettu ennalta-arvaamattomuus ei kuitenkaan tyhjene edes jokseenkin tunnettuihin muuttujiin, kuten ilmastollisiin ja sääolosuhteisiin. Haastatteluissa sienten 
oma toiminta todettiin arvaamattomaksi ja käsittämättömäksi: sieniä ei välttämättä nouse sienestäjän kaikin puolin ihanteelliseksi arvioimaan paikkaan ("jos mä oisin sieni niin mä kasvaisin tässä’), mutta toisaalta niitä saattaa nousta jonnekin muualle odottamattomasti ("minkä takia ne sitten tähän tuli [...] tässä ei ol ikinä ennen ollut'). Sienillä oli haastateltavien mukaan ihmisille vieras "sielunelämä" ja "elämänkierto": haastateltavan sanoin on hankalaa olla niiden "aivotuksista selvillä, että mistä ne saa päähänsä itiöemän putkauttaa".

Kuten Staddon (2009, 163) toteaa, sienet eivät ole vain inhimillisten intentioiden, toiminnan tai affektiivisen suuntautumisen objekteja, vaan myös subjekteja muuttuvissa vuorovaikutussuhteissa: sienet vetävät puoleensa ja liikuttavat ihmisiä (ks. myös Poe ym. 2014, 911-912), ja muuttavat ekosysteemien ja niihin kytkeytyneiden talouksien dynamiikkaa (Barron \& Hess 2020). Suomessakin poimittujen sienten määrä riippuu siitä, onko sienivuosi tärkeimpien ruokasienten osalta hyvä vai huono (Tahvanainen ym. 2019; Turtiainen $y m$. 2012). Sienten yllätyksellisyydestä kertoivat myös haastateltavien vaalimat muistot valtavista tai muuten odottamattomista sienisaaliista, ja siihen perustui osin myös sienestyksen viehätys:

\section{PH: No mikä sïnon parasta sïnä sienestämisessä?}

H3: Löytäminen. Ei sen tarvi ol monenkaan millin kokonen sieni, kun se löytämisen riemu on. Se se on bauskinta. Kun ei voi koskaan tietää, onko mitään sieniä vai löytyykö se megamesta joskus.

Tsingin (2015, 258) mukaan sienten nousemisen odottaminen muistuttaa ihmisiä riippuvuudesta ei-inhimillisen luonnon prosesseihin sekä näiden prosessien omaehtoisuudesta. Sienestyksen koetussa ennalta-arvaamattomuudessa tulee siis esiin lajien välisen yhteismuotoutumisen hallitsemattomuus, joka irrottaa sienestyksen rationaalisista, ihmiskeskeisistä tuotannon ja talouden ymmärryksistä. Reparatiivista tulkintaa seuraten sienestys tuottaa täten avoimuutta toisenlaisille, postantroposentrisillekin tulevaisuuksille: sienestys ei ole suoraviivaista ei-inhimillisten resurssien käyttöä inhimillisen toimeentulon hankkimiseksi, vaan ohjaa kohti keskinäistä toimeentuloa, jossa materiaalisten tarpeiden tyydyttäminen ja monilajisten verkostojen muodostuminen eettis-poliittisine kysymyksineen kietoutuvat erottamattomasti yhteen (ks. Hyvärinen 2017, 2019).

\section{Plantaasimaisuudet keräilyn käytännöissä}

Korvasienestäjien kanssa tehdyt kävelyhaastatteluretket veivät myllättyihin ja kurinalaistettuihin maisemiin, kuten niistä otetut kuvat havainnollistavat (kuvat 1 ja 2). Kuvissa näkyy eri-ikäisiä hakkuuaukeita, harvennettuja, nuoria ja tasarivisiä metsiä, metsäautoteitä, metsäkoneiden jälkiä ja puupinoja. Haastattelut siis sijoittuivat metsäteollisuuden rytmeissä ja plantaasioseenin ajassa eläville alueille, mikä muistuttaa, että sienestäminen ja etenkään korvasienestäminen eivät toimi irrallaan plantaasimaisesta tuotannosta. Tällöin moninaisen alkutuotannon analyysissa ei voida nojautua kehityskertomukseen, jossa osoitetaan, rajataan ja etäännytetään plantaasimaisen tuotannon ongelmat ja esitetään ei-plantaasimaisia tuotannon muotoja yksioikoisina ratkaisuina (ks. Alhojärvi 2020). Kehityskertomuksen sijaan kyseessä on hankala yhteen kietoutuminen: keräily on paitsi ei-plantaasimaisia toimeentulon käytäntöjä, myös plantaasimaisuuteen myöntymistä ja sen kanssa elämistä.

Korvasienestyksessä plantaasimainen puuntuotanto on erityisen näkyvästi läsnä, sillä korvasienet viihtyvät paikoissa, missä maan pinta on rikkoutunut ja maassa on paljon selluloosaa, esimerkiksi hakkuutähteitä. Hakkuuaukeiden lisäksi puupinojen paikat, metsäautoteiden reunat, ojanvarret sekä metsäkoneiden urat ovat otollisia korvasienten kasvupaikkoja. Pelkkä puiden kaataminen ei kuitenkaan riitä luomaan korvasienelle ihanteellisia olosuhteita: korvasienen runsastumiselle keskeistä on ollut mekaaninen maanmuokkaus, joka on Suomessa yleistynyt metsänhoidossa 1960-luvulta alkaen (Saksa 2019, 8). Vanhempi haastateltava muistaa ajan ennen laajamittaista maanmuokkausta: 

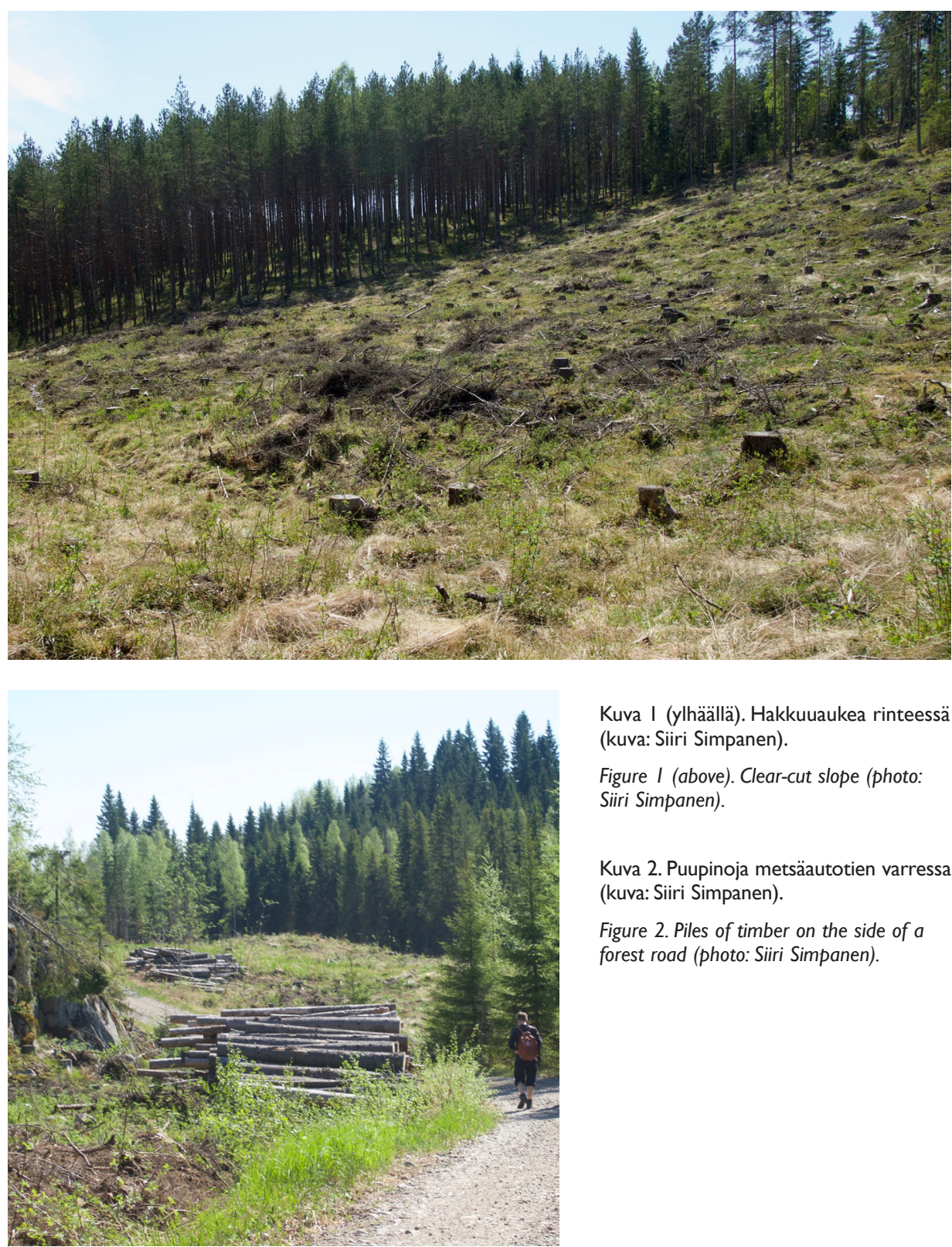

Kuva I (ylhäällä). Hakkuuaukea rinteessä (kuva: Siiri Simpanen).

Figure I (above). Clear-cut slope (photo: Siiri Simpanen).

Kuva 2. Puupinoja metsäautotien varressa (kuva: Siiri Simpanen).

Figure 2. Piles of timber on the side of a forest road (photo: Siiri Simpanen).

H9: Sehän oli sillon se elämänpiiri oli palijon pienempi ku ei ollu mettäantoteitä eikä tämmösiä ankeita, tämä koko korvasienihommahan on byvin uutta ja tuoretta tämmönen laajamittainen, se on tullu sen metsänmuokkanksen myötä. Ennen niitä oli vain jossaki polokujen varsilla ja laanipaikoilla ja sitten semmosia yksittäisiä.

Hakkuiden ja maanmuokkauksen lisäksi haastateltava mainitsee metsäautotiet keräilyä ja muutakin elämänpiiriä laajentaneina. Metsäautoteiden merkitys näkyi paitsi haastateltavien puheessa, myös haastattelutilanteissa: suurimmassa osassa haastatteluja metsäautoteitä kuljettiin pitkiäkin matkoja joko autolla tai jalan. Puunkorjuuta ja -kuljetusta varten Suomen alueelle on rakennettu lähes $160000 \mathrm{~km}$ metsäautoteitä (Greis ym. 2019, 8). Ne johdattavat hakkuuaukeiden lisäksi kasvaviin metsiin, joista poimitaan myös muita sieniä sekä marjoja. 
Korvasienestys ei siis ole ainoa keräilyn muoto, jossa hyödynnetään puuntuotannon maisemaan jättämiä jälkiä, eikä hakkuuaukeidenkaan sato rajoitu vain korvasieniin: haastateltavat kertoivat poimivansa aukeilta myös vadelmia ja metsämansikoita, ja pohjoisemmassa mustikka ja puolukka viihtyvät harvennetuissa tai jopa hakatuissa metsissä. Myös metsäkoneiden ajouria hyödynnettiin korvasienten poimimisen lisäksi metsässä liikkumisessa ja suunnistamisessa (kuva 3).

Näin keräilyn monilajisissa talouksissa hyödynnetään puuplantaasien ylijäämää (ks. Eskelinen ym. 2020, 2): korvasienet ja marjakasvit käyttävät hakkuiden myötä lisääntyneitä ravinteita, valoa ja lämpöä (ks. Koivula \& Vanha-Majamaa 2020), ja keräilijät ottavat talteen näin syntyviä puuntuotannolle tarpeettomia tuotteita ja metsäautoteillä kulkiessaan valjastavat metsäteollisuuden infrastruktuuria uuteen käyttöön. Tässä mielessä keräilyn suhde plantaasitalouksiin on kommensalistinen: puuplantaaseja hyödynnetään keräilyssä ilman, että niille tuotetaan haittaa, tai jopa plantaasituotannon imagolle suotuisasti. Metsäteollisuuden toimijat tuovat mielellään esiin keräilyn ja puuntuotannon rinnakkaiselon mahdollisuuksia (ks. esim. Makkonen 2008; Salin 2018). Korvasienet ovat rinnakkaiselosta äärimmäinen, jopa groteski esimerkki, ja niitä onkin hyödynnetty osoituksena hakkuuaukeiden käyttökelpoisuudesta (Hannelius \& Kuusela 1995, 175; ks. Tsing 2015, 174). Paranoidisti tulkiten korvasientä voikin tarkastella plantaasiosentrismin osallisena, valjastettuna metsäteollisuuden tahattomaksi kätyriksi, joka sopeuttaa sienestäjiä puuplantaasien kanssa toimeen tulemiseen. Korvasienten (mahdollinen) läsnäolo sai haastateltavat lähestymään hakkuuaukkoja uteliaisuudella ja jopa innostuksella:

H8: [...J]atkettiin sieltä sitten [joelle] Ruotsiin kalaan [...]. [Joki] on kablitsematon joki, aivan valtavan bieno iso koski on sïnä. Pikkusen ennen sitä paikkaa oli semmonen aivan mielettömän byvän näkönen iso hakkunaukio, ja mää pojalle sanoin, että mun on kyllä pakko pysähtyä kattoon.

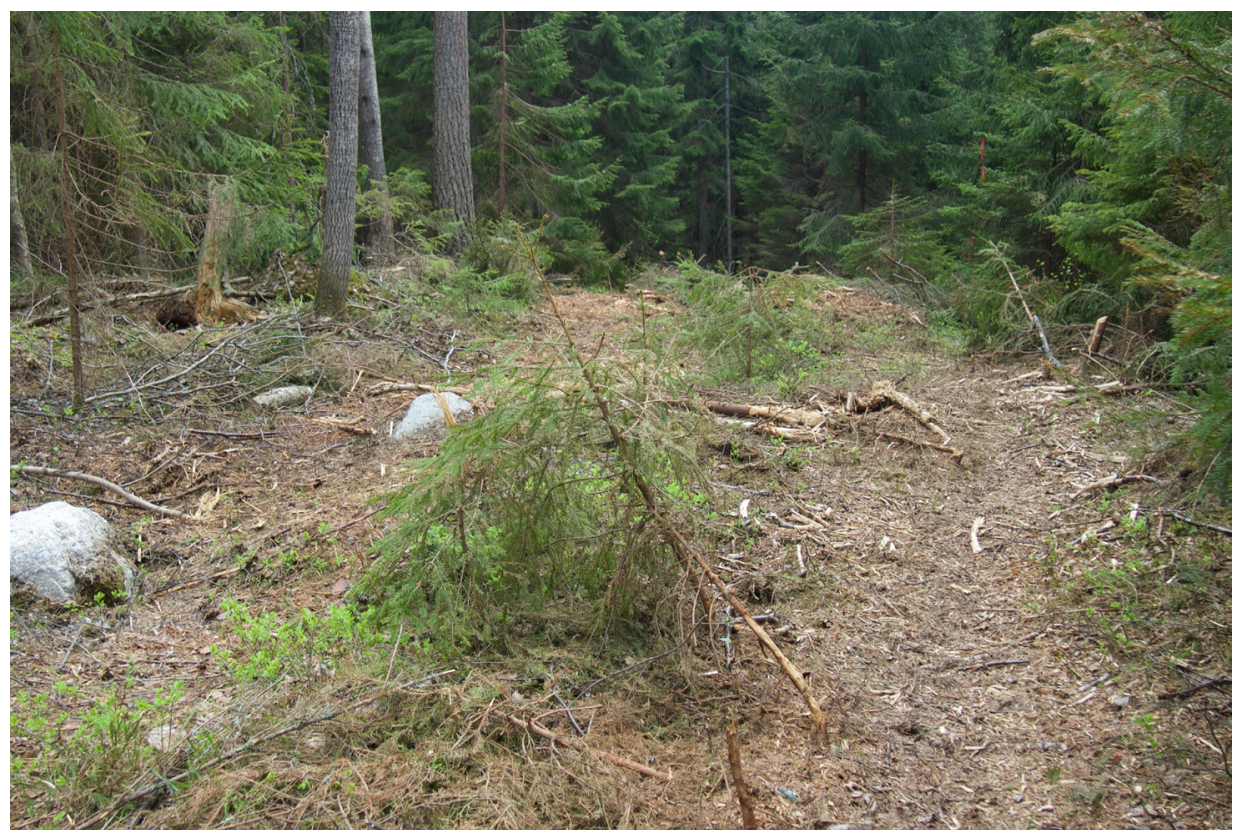

Kuva 3. Metsäkoneen jälkiä (kuva: Siiri Simpanen).

Figure 3. Tracks left by a forest harvester (photo: Siiri Simpanen). 
Sitaatissa laajan hakkuuaukean ja sähköntuotantoon valjastamattoman kosken rinnakkaisuus vielä korostaa, miten moni-ilmeistä suhtautuminen ihmisen muokkaamaan ei-inhimilliseen luontoon voi olla. Vastaavasti monet haastateltavat kertoivat nauttivansa metsässä oleskelusta, mutta eivät kokeneet hakkuaukoilla kulkemista sen vastakohtana, vaikka maisema onkin erään haastateltavan sanoin "mabdollisimman ruma". Plantaasimaisuus hyväksytään ja sen kanssa opitaan elämään silloinkin, kun hakkuut osuvat tutun sienimetsän kohdalle.

H9: VTïme talavenaki hakattiin semmonen, mistä minä oon runkannut rouskut kerätä, ihan aukiaksi, että siellä ei ennää minun elämän aikana oo rouskuja sïnä kobti. Pittää katella eri paika[-] sïnä meni berkekutattipaikat kans. Mutta se kuuluu tähän systeemün, en minä sitä sinänsä harmittele. Ne on vain ollu siinä byvällä hollilla [...] läbellä siinä.

Hakkuun aiheuttama ajallinen katkos on yksilön näkökulmasta ylittämätön, sillä sienimetsän uudistumiseen menee lähes ihmisikä. Sopeutumista hakkuisiin voi kuitenkin ymmärtää reparatiivisen näkökulman kautta, jossa avoimuus yllättymisille tarkoittaa myös ikävien yllätysten mahdollisuuden hyväksymistä (Sedgwick 2003, 146). Avohakkuut ovat haastateltavan näkökulmasta itsestään selvä osa "systeemiä" eli tulkintani mukaan plantaasimaista tuotannon tapaa, mutta tämän systeemin nimeämisen voi myös lukea muiden järjestysten mahdollisuuden tunnistamisena, mitä tukee haastateltavan korkeahko ikä: hän on kertomansakin mukaan ehtinyt nähdä myös muunlaisia metsän alkutuotannon tapoja (ks. sitaatti edellä).

Kaksi haastateltavaa ilmaisivat selkeämmin vastustaneensa avohakkuisiin perustuvaa metsätaloutta, toinen paikallisessa metsäkiistassa ja toinen allekirjoittamalla avohakkuita vastustavan kansalaisaloitteen. Vastustamista ei suoraan merkityksellistetty keräilyn puolustamisena, mutta muissa osissa aineistoa vastakkainasettelu plantaasimaisen tuotannon ja keräilyn käytäntöjen välillä tuli esiin. Esimerkiksi erityisen intensiiviselle puuntuotantoalueelle muuttanut haastateltava kuvailee sienestämistä antagonistisessa hengessä kilpailuksi metsäkoneiden kanssa: "Jos näkee jonku byvän metsän, nïn sinne on mentävä beti ku buomen se voi olla poissa".

Sienestäminen kilpajuoksuna tai hakkuiden tieltä seuraaville sienimaille siirtyminen eivät kuitenkaan ole kaikille mahdollisia tapoja turvata toimeentuloa. Läheinen sienimetsä voi olla huonojalkaiselle poimijalle korvaamaton, ja monille ei-inhimillisille eliöille paikallisen hakkuun tuottama tuho voi olla lopullinen: esimerkiksi puiden kanssa symbioosissa kasvaviin mykorritsasieniin hakkuut vaikuttavat voimakkaan haitallisesti (Salo 2019). Niiden ei aina tarvitse edes osua sienimetsän kohdalle, sillä puuston harveneminen tai häviäminen voi vaikuttaa myös lähialueisiin:

H2: Yhes paikeaa on ollut tosi byvä ja siit hakattiin sellai iso kunsikeko pois edest, ei sitä bakattu edes sitä kobtaa mis nït [kantarelleja] on kasvanut tosi paljon. Se auringon valo varmaan teki sen, se tuli tosi paljon valoisammaks, niin ne loukkaantu, ne ei tullut.

PH: Tuleeks semmosille paikoille jotain toista sientä vai häviää ihan kokonaan?

H2: Mun mielest sielä ei ole kasvanu oikeen mitään. Semmosta se on.

Plantaasimainen tuotanto muuttaa elämää myös varsinaisten plantaasien ulkopuolella: sienten elinkiertojen lisäksi esimerkiksi vesistöjen ekosysteemit ovat muuttuneet, kun soita on ojitettu puuntuotantoa varten (Nieminen ym. 2017; ks. myös Pohjanmies ym. 2017). Paikallisiin eliöyhteisöihin kiinnittyneet inhimillisen toimeentulon käytännöt ja kulttuurit ovat niin ikään järjestyneet uudelleen, kun plantaasimaisuus on suhteellisen lyhyessä ajassa levinnyt ja juurtunut syvälle alkutuotantoon (ks. myös Escobar 2008). Nuorempi haastateltava kuvailee vanhempiensa toimeentulon kytkeytymistä puuntuotantoon: 
H7: [...] Se on mun vanhempien toimeentulo, eik. ä niillä ole [...] ei mun isä voi olla silleen, et suojelen nämä metsäni ja menen johonki palkkatöihin, en tiedä pystyiskö se palk.katöihin [naurabtaa]. Ja muntenkin, se on ikänsä viljelly näit metsii ja se on tebnyt töitä niin et ois saanu [niistä] toimeentuloa, en mä koe et mulla ois mitään sanottavaa siihen, että ei että kyllä teiän pitää labjoittaa palk.kanne luonnolle tai jotain.

Vanhempiensa vaihtoehdottomuuden lisäksi haastateltava tunnistaa myös oman riippuvuutensa hakkuista: työttömänä hän kertoo käyttävänsä paljon vanhempiensa resursseja. Esimerkki osoittaa, miten plantaasiosentrismi ei ole vain diskursiivista, vaan kyse on kouriintuntuvista toimeentulon mahdollisuuksista, jotka lisäksi välittyvät hoivasuhteissa. Alkutuotantoon perustuvassa toimeentulossa liikkumavara plantaasien talouksien ulkopuolelle voi olla vähissä, jos olemassa oleva tuotannon infrastruktuuri, kulttuuriset mallit, elintasoon kohdistuvat odotukset sekä alkutuotantoa koskeva politiikka ohjaavat plantaasien suuntaan. Rahataloudelliset laskelmat metsien erilaisten tuotteiden arvosta tukevat tätä kokemusta:

H7: Mä oon miettinyt sienten myymisen ybteydessä, et jos niist sienist vois saada elantoo, et miten muuten siit metsästä vois saada elantoa ku siit puusta. Mut sit mä oon et okei nää on aika masentavat laskelmat, koska siis, ku kattoo tos on vaik, tollanen täyskasvunen kunsi, tollanen paksumpi, nïn toi yks pun nïn tosta sais jonkun satasen, sata euroo jos kaatais ja myis. Jos mä keräisin tosta alueelta sieniä, niin vaik mä keräisin jokaikisen syötävän sienen joka siinä kasvaa [naurabtaa] ja myisin sen kovaan bintaan, nïn.

Laskelma puhuu karusti plantaasimaisen tuotannon puolesta: kuusen kaataminen on haastateltavan arvion mukaan rahallisesti selkeästi kannattavampaa kuin jo itsessään utopistinen ajatus kaikkien sen kanssa yhteistyössä kasvavien syötävien sienten keräämisestä. Luvuissa on vääjäämättömyyttä, jonka merkityksen paranoidi tulkitsija jo tietääkin: plantaasien maantieteellisessä tai kulttuurisessa läheisyydessä keräilytalouksien toimeentulo ei ole irrallaan puu- ja paperiteollisuuden globaaleista tuotantoketjuista ja puuperustaisten hyödykkeiden hinnanmääräytymisen prosesseista, vaan kytkeytyy niihin auttamatta tuotannon tapojen vertailun ja vastakkainasettelun kautta.

Toisenlaisissa keräilyn konteksteissa globaalit luonnontuotteiden ja työn markkinat heilahteluineen ovat vielä selkeämmin osa toimeentuloa. Suomeen on tullut viimeisen vuosikymmenen ajan vuosittain tuhansia ulkomaalaisia poimijoita, jotka keräävät kaupallisiin tarkoituksiin lähinnä mustikkaa ja puolukkaa, mutta pienissä määrin myös sieniä (Rantanen \& Valkonen 2011, 9-11). Poimijoiden maahantulon, majoituksen ja kuljetukset järjestävät marja-alan yritykset, jotka myyvät heidän keräämänsä marjat elintarviketeollisuuden käyttöön Suomeen ja ulkomaille. Poiminta ei tapahdu työsuhteessa tuntiperusteisella palkkiolla, vaan poimijoille maksetaan marjoista kilohinta, joka määräytyy sekä paikallisten (Tahvanainen ym. 2019) että muiden marjanpoiminta-alueiden satonäkymien mukaan osana globaaleja ruokamarkkinoita (Rantanen \& Valkonen 2011, 7-8, 76-77). Globaalien tuotantoketjujen osana toimimisen lisäksi metsämarjanpoimijoiden työ muistuttaa monilta muiltakin osin plantaasimaista työtä: se on siirrettyä, kollektiivista, tarkkaan aikataulutettua ja keskusjohtoista, ja siinä on ainakin osin vaihtoehdottomuutta ja jopa pakkoa, sillä poimijat ovat monin tavoin riippuvaisia marjayrityksestä. Usein poimijat ovat myös ottaneet matkakustannuksia varten lainaa, jolloin velkaantumisen pelko voi ajaa työskentelemään koetuista epäkohdista huolimatta (emt; ks. myös Eriksson \& Tollefsen 2013; Lauren \& Prokkola 2017). Poimijoiden kuvaukset työn raskaudesta (Rantanen \& Valkonen 2011, 60) asettuvatkin jyrkkään vastakohtaan suhteessa haastateltujen sienestäjien kokemuksiin metsässä oleskelun ja keräilyn tuottamasta hyvinvoinnista.

Keräilyn järjestyminen plantaasimaiseksi työksi vaikuttaa siis edellyttävän, että poimijoita ei suojaa vauraan hyvinvointivaltion jäsenyys. Suomalaisen maa- ja metsätaloustuotannon riippuvuus ulkomaisista siirtotyöntekijöistä nousi julkiseen keskusteluun keväällä ja kesällä 
2020 koronaviruspandemian aiheuttamien matkustusrajoitusten myötä. Keskustelut työn luonteesta ja suomalaisten kyvyistä ja halukkuudesta osallistua siihen osoittivat, miten hankala matalapalkkaista plantaasimaista työtä on sovittaa korkean tulotason hyvinvointivaltioon ilman sen etuuksien ja turvan ulkopuolelle rajattuja, alemman tulotason maista siirrettyjä työntekijöitä. Työ poiminnan parissa voi olla kuitenkin tarpeen myös silloin, kun hyvinvointivaltion jäsenelleen suoma toimeentulon turva on ohutta tai repaleista:

\section{H6: [...N]e peräkamarin pojat, [...] keräs siellä alueella niitä korvasieniä myyntiin oikeesti lisäansioksi, kummallakaan ei ees ollut, toinen oli sairaseläkkeeellä, ei oikeen semmost, ei ne tehny oikeen mitään oikeeta työtä tai silleen, varmaan se raba on ollut heille tarpeen, se korvasienistä tullu raha. [...] Itse kun Kainuusta [paikkakunta] tulee nïn minä kyllä ymmärrän sen birveän hyvin että se on luonnosta nïn marjojen ku sienten poimiminenki on ihan oikeesti elämisen jatke sille toimeentulolle [...].}

Keräily toimeentulon osana ei kuitenkaan väistämättä tarkoita vaihtoehdottomuutta: haastateltaville itselleen toimeentulon eriasteinen nojaaminen keräilyyn ei vaikuttanut pakon sanelemalta. Myöskään keräilytyön mahdolliset plantaasimaiset piirteet eivät tarkoita, että työ tai sen tekijä olisivat yksinomaan plantaasimaisuuden määrittelemiä. Moninaisten talouksien näkökulmasta siirtolaisuutta tarkastelevat Safri \& Graham (2015) varoittavat kehystämästä siirtotyöläisten elämää yksioikoisesti menetyksen ja sorron narratiivien kautta ja ehdottavat sen sijaan siirtolaisten työn, rahavirtojen ja ylirajaisen hoivan muodostamaa globaalia kotitaloutta kategoriaksi ja toimijaksi muiden kansainvälisen finanssitalouden toimijoiden rinnalle. Vastaavalla reparatiivisella otteella marjojen poimintaa puuplantaaseilla voi tulkita paitsi osana globaalisti eriarvoisia työn ja tuotannon järjestyksiä, myös moniulotteisina henkilöhistorioina, kulttuurisina kohtaamisina ja tulevaisuuksien toisenlaiseksi tekemisenä, joita Tsing (2015) kuvaa tuoksuvalmuskan poimijoiden parissa Yhdysvalloissa, Kiinassa ja Japanissa.

Tsing (2015, 63-66) määrittelee tuoksuvalmuskan keräilyn perikapitalistiseksi työksi, joka on samaan aikaan kapitalismin ulko- ja sisäpuolella, määrittyen sekä osana kapitalistisia tuotantosuhteita että moninaisia ei-kapitalistisia suhteita ja ei-inhimillisen luonnon prosesseja. Samaan tapaan keräily moninaisissa muodoissaan kytkeytyy plantaasimaiseen tuotantoon esimerkiksi yllä kuvatuissa kommensalistisissa ja antagonistisissa suhteissa sekä plantaasiosentristen paikallisten ja globaalien järjestysten kautta, mutta ei siitä huolimatta määrity yksiselitteisesti plantaasien talouksien osaksi. Edellisessä luvussa kuvaillut keräilytalouksien arkiset käytännöt ja merkitykset moninaisessa ei-plantaasimaisuudessaan ovat läsnä samanaikaisesti plantaasimaisuuteen myöntymisen ja sen kanssa toimeen tulemisen kanssa. Tämä ristiriitaisuus itsessään on haaste plantaasiosentrismille, joka perustuu ilmiöiden ryhmittymiseen suhteessa ensisijaistettuun plantaasituotantoon. Hajanainen ja erilaisia merkityksiä saava keräily ei asetu pysyvästi ja suoraviivaisesti yhdenlaiseen suhteeseen plantaaseihin nähden, vaan liikkuu osana monimutkaisia ja muuttuvia keskinäisen toimeentulon verkostoja.

\section{Lopuksi}

Plantaasiosentrismin osittaisuuden ja tilanteisuuden analyysi edellyttää herkästi paikantuvaa ja paikantumisestaan tietoista tarkastelua, jota olen tässä artikkelissa toteuttanut etnografisen tiheän kuvauksen kautta sekä reparatiivisen ja paranoidin lähestymistavan vuoropuhelulla. Olen ensinnäkin tarkastellut, miten metsiin paikantuvaa alkutuotantoa voi ymmärtää toisin kuin plantaasiosentrisesti. Lukemalla esiin eroja postkapitalistisen metodologian mukaisesti sienestystä ja muuta keräilyä on mahdollista tarkastella esimerkkinä metsien talouksien ja niiden mahdollistaman toimeentulon moninaisuudesta, joka haastaa plantaasiosentrismin yksipuolistavaa ymmärrystä alkutuotannosta. Siinä missä plantaaseilla tuotanto perustuu 
radikaaliin yksinkertaistamiseen ja kurinalaistamiseen, sienestyksessä opitaan tulemaan toimeen metsän arvaamattoman moninaisuuden kanssa. Toimeentulo perustuu usein pitkäjänteiseen paikantumiseen sienimetsien monilajisiin verkostoihin, joiden rinnalla plantaasitalouksien vieraannuttavat käytännöt ja ajalliset katkokset näyttäytyvät väkivaltaisina. Plantaasimainen pakotettu, globaaleja tuotantoketjuja palveleva työ on niin ikään usein kaukana sienestyksen arkisista käytännöistä, jotka pakenevat työn määritelmiä ja kiinnittyvät paikallisverkostoihin ja lähisuhteisiin. Reparatiiviseen tulkintaan nojaava analyysi näyttää sienestyksen paikallisessa ja tilanteisessa kontekstissaan toimintana, jossa ylläpidetään ja toteutetaan unelmia palkkatyön ulkopuolisesta toimeentulosta ja jossa luodaan henkilökohtaisia ja merkityksellisiä suhteita ruoantuotannossa mukana oleviin toisiin. Näin sienestys ja pienimuotoinen ruoantuotanto yleisemminkin antavat aineksia utopioille sellaisista toimeentulon tavoista, jotka eivät ole ristiriidassa koetun ja jaetun hyvinvoinnin kanssa.

Sienestys myös mahdollistaa talouden näkökulmien laajentamisen inhimillisestä toimeentulosta siihen, miten sen tuottamisessa ollaan osa elämää ylläpitäviä verkostoja. Toimeentulo, jota keräilyn käytännöissä tuotetaan, on toki myös inhimillistä, sienestäjien ja heidän läheistensä ja kaukaisempienkin sienten kuluttajien elettyä arkea. Samalla sienestyksessä kuitenkin kiinnitytään kerättyjen ja keräämättä jätettyjen sienten, kaadettujen ja kasvavien puiden, auton tuulilasiin liiskaantuneiden ja sienijätteistä sikiävien hyönteisten sekä tuotettujen ja tuottamatta jätettyjen hiilidioksiditonnien myötä monimutkaiseen inhimillisen ja ei-inhimillisen elämän jatkuvuuksien ja katkosten kudelmaan.

Sienestyksen tarkastelu ei kuitenkaan pääty plantaasiosentrismin kritiikin pohjalle rakentuvien moninaisten ja monilajisten keräilytalouksien mahdollisuuksiin. Puuntuotantoon keskittyvät metsätalouden muodot ovat läsnä myös keräilyssä, sekä sen arkisissa käytännöissä että siihen kiinnittyvissä merkityksissä ja sitä koskevissa ymmärryksissä, mitä korvasienestys erityisesti alleviivaa. Plantaasimaisen tuotannon ylijäämä ja infrastruktuuri edesauttavat sienestystä, kun taas sen kiihtyvät ajalliset syklit aiheuttavat keräilytalouksille ja niissä mukana oleville toimijoille vakaviakin häiriöitä. Alkutuotannon plantaasiosentriset järjestykset ja normit hankaloittavat keräilyyn perustuvien talouksien mahdollisuuksien kuvittelua, ja leviävät myös keräilytyön käytäntöihin siellä, missä toimeentulon vaihtoehdot ovat rajatummat.

Kuten plantaasiosentrismin käsitteeseen ja kritiikkiin sisältyvä paranoia hyvin tietää, sienestys ei tapahdu plantaasimaisen tuotannon ulkopuolella. Plantaasit ja plantaasimaiset käytännöt eivät kuitenkaan ole ainoita, tyhjentäviä tai lähtökohtaisesti ensisijaisia keräilyä määrittäviä tekijöitä. Esimerkiksi analyysissa esiin nousseet sienestäjien sosiaaliset suhteet ja hyvinvointivaltion järjestykset muokkaavat sienestystä, samoin kuin arvaamaton ei-inhimillinen toimijuus kaikessa moninaisuudessaan. Sienestyksen eletyssä arjessa erilaiset määrittävät tekijät lomittuvat toisiinsa ja tuottavat uusia merkityksiä: esimerkiksi korvasienten perässä hakkuaukeilla kulkeminen teki alueet haastateltaville (ja haastattelijalle) erityisiksi. Tällöin ne eivät olleet vain menetetty sienimetsä mutta eivät myöskään yksinomaan puuplantaasin pohjaa ja siten vieraannutettua ja etäistä tuotantopanosta, vaan tilanteisesti muotoutuvien muistojen ja merkitysten kyllästämiä paikkoja. Vaikka hakkuuaukeille paikantumista tuskin voi pitää antiplantaasiosentrisenä käytäntönä, sen voi kuitenkin reparatiivisesti nähdä järjestävän uusiksi plantaasimaisia suhteita ja mahdollistavan ennalta-arvaamattomiakin ei-plantaasimaisen toimeentulon ja siihen kietoutuneen hyvinvoinnin käytäntöjä.

Sinnikäs sopeutuminen häiriöitä aiheuttaviin alkutuotannon ja talouden käytäntöihin on keräilyn samanaikaisen menestystarinan ja tragedian ytimessä. Keräily hajaantuneena, tilanteisena, joustavana ja osittaisena toimeentulon muotona löytää yhä uusia ilmenemismuotoja ja jopa kukoistaa plantaasien ja muiden väkivaltaisten talouden käytäntöjen raunioittamilla seuduilla. Paranoidi positio houkuttelee tulkitsemaan keräilyn elinvoimaisuuden osallisuudeksi plantaasiosentrismiin ja asettaa analyysin päämääräksi 
tämän osallisuuden paljastamisen, minkä tehtävän voin katsoa osaltani täytetyksi. Samalla olen reparatiivisten tulkintojen kautta pyrkinyt luomaan ymmärrystä sienestyksestä toimeen tulemisena plantaasien kanssa ja niistä huolimatta: samanaikaisena sopeutumisena plantaasimaisen alkutuotannon väkivaltaisuuksiin että toimeentulon tuottamisena tavoilla, jotka kantavat plantaasioseenin ohitse ja ylitse.

\section{Kiitokset}

Kiitän nimettömiä arvioijia, päätoimittaja Heikki Sirviötä sekä ohjaajiani, erityisesti Riikka Homasta tarkkanäköisistä ja kannustavista kommenteista käsikirjoitukseen. Lisäksi haluan kiittää haastateltaviani antoisista sieniretkistä sekä Siiri Simpasta ja Noora Mäkilää näiden retkien valokuvaamisesta. Tutkimus on osa Koneen säätiön rahoittamaa tutkimusprojektia.

\section{Lähteet}

Alam, S. (2008) Majority World: Challenging the West's Rhetoric of Democracy. Amerasia Journal34(1) 89-98.

Alhojärvi, T. (2020) Critical Gibson-Graham: Reading Capitalocentrism for Trouble. Rethinking Marxism 32(3) 286-309. https://doi.org/10.1080/08935696.2020.1780667

Barron, E. \& Hess, J. (2020) Non-human 'labour': the work of Earth Others. Teoksessa Gibson-Graham, J. K. \& Domborski, K. (toim.) The Handbook of Diverse Economies, 163-169. Edward Elgar, Cheltenham \& Northampton

Barron, E. (2015) Situating wild product gathering in a diverse economy: Negotiating ethical interactions with natural resources. Teoksessa Roelvink, G., St. Martin K \& Gibson-Graham, J.K. (toim.) Making Other Worlds Possible: Performing Diverse Economies, 173-193. University of Minnesota Press, Minneapolis.

Bennett, J. (2007) Edible Matter. New Left Review 45, May-June 2007, 133-145.

Burnette, C. E., Clark, C. B. \& Rodning, C. B. (2018) "Living off the Land": How Subsistence Promotes Well-Being and Resilience among Indigenous Peoples of the Southeastern United States. Social Service Review, September 2018, 369-400. https://doi.org/10.1086/699287

Callon, M. (toim.) (1998) The Laws of Markets. Blackwell, Malden.

Diez, J. M., James, T. Y., McMunn, M. \& Ibáñez, I. (2013) Predicting species-specific responses of fungi to climatic variation using historical records. Global Change Biology 19, 3145-3154. https://doi.org/10.1111/ gcb.12278

Emery, M. R. (2001) Who Knows? Local Non-Timber Forest Product Knowledge and Stewardship Practices in Northern Michigan.” Journal of Sustainable Forestry 13(3/4), 123-139.

Emery, M. R. \& Pierce, A. R. (2005) Interrupting the telos: locating subsistence in contemporary US forests. Environment and Planning A, 37, 981-993.

Encyclopaedia Britannica (2017) Plantation. < https://www.britannica.com/topic/plantation-agriculture>. 27.5.2020

Eriksson, M \& Tollefsen A. (2013) Of berries and seasonal work. Teoksessa Geiger, M. \& Pecoud, A. (toim.) Disciplining the transnational mobility of people, 185-206. Palgrave Macmillan, Lontoo.

Escobar, A. (2008) Territories of Difference. Place, Movements, Life, Redes. Duke University Press, Durham \& Lontoo.

Eskelinen, T., Hirvilammi, T. \& Venäläinen J. (2020) Introduction: Community economies and social transformation with, within and beyond the welfare state. Teoksessa Eskelinen, T., Venäläinen, J. \& Hirvilammi, T. (toim.) Enacting Community Economies Within a Welfare State, 1-21. MayFly Books, Colchester.

FAO (2020a) Global Forest Resource Assessment 2020. Report. Finland. Food and Agriculture Organization of the United Nations, Rooma.

FAO (2020b) Global Forest Resource Assessment 2020. Terms and Definitions. Food and Agriculture Organization of the United Nations, Rooma.

Gibson-Graham, J.K. (2014) Rethinking the Economy with Thick Description and Weak Theory. Current Anthropology 55(59), S147-S153. http://www.jstor.org/stable/10.1086/676646

Gibson-Graham, J. K. (2008) Diverse economies: performative practices for 'other worlds'. Progress in Human Geography 32(5), 613-632. https://doi.org/10.1177/0309132508090821

Gibson-Graham, J. K. (2006a) The End of Capitalism (As We Knew It). A Feminist Critique of Political Economy. Minnesota University Press, Minneapolis.

Gibson-Graham, J. K. (2006b) A Postcapitalist Politics. Minnesota University Press, Minneapolis.

Gibson-Graham, J. K. \& Domborski, K. (toim.) (2020) The Handbook of Diverse Economies. Edward Elgar, Cheltenham \& Northampton. 
Gibson-Graham, J.K. \& Miller, E. (2015) Economy as ecological livelihood. Teoksessa Gibson, K., Rose, D.B. \& Fincher, R. (toim.) Manifesto for Living in the Anthropocene, 7-16. Punctum Books, New York.

Greis, I., Perälä, M., Perälä, T. \& Teppo, M. (toim.) (2019). Metsänhoidon suositukset metsäteiden kunnossapitoon, työopas. Tapion julkaisuja.

Hannelius, S. \& Kuusela, K. (1995) Pohjoisen havumetsän maa. Forssan kirjapaino, Forssa.

Haraway, D. (2016) Staying with the Trouble. Making Kin in the Chthulucene. Duke University Press, Durham.

Haraway, D. (2015) Anthropocene, Capitalocene, Plantationocene, Chthulucene: Making Kin. Environmental Humanities 6 159-165.

Haraway, D. (2008) When Species Meet. University of Minnesota Press, Minneapolis.

Haraway, D. (2003) Companion Species Manifesto. Dogs, People, and Significant Otherness. Prickly Paradigm Press, Chicago.

Haraway, D., Ishikawa, N., Scott, G., Olwig, K., Tsing, A. L.\& Bubandt, N. (2015) Anthropologists Are Talking - About the Anthropocene. Ethnos 81(3) 535-564. https://doi.org/10.1080/00141844.2015.1105838

Haraway, D. \& Tsing, A. (2019) Reflections on the Plantationocene. A conversation moderated by Gregg Mitman. Edge Effects.

Hirvilammi, T. (2015) Kestävän byvinvoinnin jälilllä. Ekologisten kysymysten integroiminen byvinvointitutkimukseen. Sosiaali- ja terveysturvan tutkimuksia 136. Kela, Helsinki.

Hyvärinen, P. (2019) Beekeeping expertise as situated knowing in precarious multispecies livelihoods. Sosiologia 59(4) 365-381.

Hyvärinen, P. (2017) Ruoantuotannon ristiriitoja rikkaruohonjuuritasolla. Kitkeminen työnä, tiedontuotantona ja tulevaisuuksien tekemisenä. Sukupuolentutkimus-Genusforskning 30(2) 35-48.

Jokinen, M. (2019) Lapin ympäristökiistojen kulttuuriset tekijät. Akateeminen väitöskirja. Helsingin yliopisto, Bio- ja ympäristötieteellinen tiedekunta. https://doi.org/10.14214/df.281

Juutinen, A. (2011) Metsien monikäytön arvottaminen. Päättäjien Metsäakatemia 19.5.2011. <https://smy.fi/wpcontent/uploads/2015/02/PMA30-ArttiJuutinen_diat.pdf>. 20.5.2020.

Kaaronen, R. O. (2020) Mycological rationality: Heuristics, perception and decision-making in mushroom foraging. Judgment and Decision Making 15(5) 630-647.

Kasanen, M. \& Heikkinen, H. I. (2012) Power relations in the decision-making processes of forest owners in Northern Finland. Nordia Geographical Publications 41(5) 83-93.

Kauserud, H., Heegaard, E., Semenov, M. A., Boddy, L., Halvorsen, R., Stige, L. C., Sparks, T. H., Gange, A. C. \& Stenseth, N. C. (2010) Climate change and spring-fruiting fungi. Proceedings of the Royal Society B 277 1169-1177. https://doi.org/10.1098/rspb.2009.1537

Kekkonen, K. (2011) "Hyvää vaubtia metsätöille" Punnkorjun ja Suomi muntoksessa. Akateeminen väitöskirja. Tampereen yliopisto, Yhteiskunta- ja kulttuuritieteiden yksikkö. http://urn.fi/urn:isbn:978-951-44-8572-5

Koivula, M. \& Vanha-Majamaa, I. (2020) Experimental evidence on biodiversity impacts of variable retention forestry, prescribed burning, and deadwood manipulation in Fennoscandia. Ecological Processes 9(11). https:// doi.org/10.1186/s13717-019-0209-1

Korhonen, M. (1990) Uusi sienikirja. Otava, Keuruu. 4. p.

Korpilahti, E. (2008) Metsätalous ja metsien käytön tulevaisuus. Metsätieteen aikakauskirja 4 253-254.

Kotilainen, J \& Rytteri, T. (2011) Transformation of forest policy regimes in Finland since the 19th century. Journal of Historical Geography 37(4) 429-439. https://doi.org/10.1016/j.jhg.2011.04.003

Kröger, M. \& Raitio, K. (2017) Finnish forest policy in the era of bioeconomy: A pathway to sustainability? Forest Policy and Economics 77 6-15. https://doi.org/10.1016/j.forpol.2016.12.003

Kuokkanen, R. (2020) The Deatnu Agreement: a contemporary wall of settler colonialism, Settler Colonial Studies. https://doi.org/10.1080/2201473X.2020.1794211

Lauren, M. \& Prokkola, E.-K. (2017) Making labour mobile: Borders, precarity, and the competitive state in Finnish migration politics. Political Geograpby 60 143-153. https://doi.org/10.1016/j.polgeo.2017.07.009

Lavola, A. (2019) Luonnonvaraisten kerä̈lytuotteiden valmistus-, pakkaus- ja myyntitoimenpiteistä. Mahdollisuuksia jatkojalostukseen -hanke, Itä-Suomen yliopisto. 2.4.2019. http://pkky-wp.pkky.fi/luonnostatuotteeksi/ wp-content/uploads/2018/12/Ker\%C3\%A4ilytuotteiden-myyntitoimenpiteist \%C3\%A4.pdf

Luonnonvarakeskus (2016) Metsätalous, marjat ja sienet. <https://www.luke.fi/tietoa-luonnonvaroista/ metsa/metsien-monikaytto/metsatalous-marjat-ja-sienet/>. 29.5.2020

Lähde, E. (2016) Näe metsä puilta. Esseitä, kolumneita ja pakinoita matkan varrelta. Arator, Helsinki.

MacKenzie, D., Muniesa, F. \& Siu, L. (toim.) (2007) Do Economists Make Markets? On the Performativity of Economics. Princeton University Press, Princeton.

Makkonen, J. (2008) Suomen metsät ovat monikäyttöisiä. Metsäteollisuus ry. 18.11.2008<https://www. metsateollisuus.fi/tiedotteet/suomen-metsat-ovat-monikayttoisia > 15.6.2020

Metsäkeskus (2018) Metsien jatkuva kasvatus yleistyy tulevaisundessa. 4.6.2018< <ttps://www.metsakeskus.fi/ tiedotteet/metsien-jatkuva-kasvatus-yleistyy-tulevaisuudessa>. 11.6.2020

Miller, E. (2020) More-than-human agency: from the human economy to ecological livelihoods. Teoksessa 
Gibson-Graham, J. K. \& Domborski, K. (toim.) The Handbook of Diverse Economies, 402-410. Edward Elgar, Cheltenham \& Northampton.

Miller, E. (2019) Reimagining Livelihoods. Life beyond Economy, Society, and Environment. University of Minnesota Press, Minneapolis.

Miltz, S. W. (1986) Sweetness and Power. The Place of Sugar in Modern History. Penguin Books, New York.

Morrow, O. \& Dombroski, K. (2015) Enacting post-capitalist politics through the sites and practices of social reproduction. Teoksessa Meehan K. \& Strauss, K. (toim.) Precarious Worlds: New Geographies of Social Reproduction, 82-98. University of Georgia Press, Athens.

Nieminen, M., Sallantaus, T., Ukonmaanaho, L., Nieminen, T. M. \& Sarkkola, S. (2017) Nitrogen and phosphorus concentrations in discharge from drained peatland forests are increasing. Science of The Total Environment 609 974-981. https://doi.org/10.1016/j.scitotenv.2017.07.210

Pagano, M. C. \& Dhar, P. P. (2016) Arbuscular Mycorrhizal Fungi under Monoculture Farming: A Review. Teoksessa Nath, T. K. \& O’Reilly, P. (toim.) Monoculture Farming: Global Practices, Ecological Impact and Benefits/ Drawbacks, 161-170. Nova Publishers, New York.

Poe, M. R., LeCompte, J., McLain, R. \& Hurley, P. (2014) Urban foraging and the relational ecologies of belonging. Social \& Cultural Geography 15(8) 901-919. https://doi.org/10.1080/14649365.2014.908232

Pohjanmies, T., Triviño, M., Le Tortorec, E., Mazziotta, A., Snäll, T. \& Mönkkönen, M. (2017) Impacts of forestry on boreal forests: An ecosystem services perspective. Ambio 46 743-755. https://doi.org/10.1007/ s13280-017-0919-5

Potts, S.. G., Biesmeijer J. S., Kremen, C., Neumann, P., Schweiger, O., \& Kunin, W. E. (2010) Global Pollinator Declines: Trends, Impacts and Drivers. Trends in Ecology and Evolution 25(6) 345-353. https:// doi.org/10.1016/j.tree.2010.01.007

Pouta, E., Sievänen, T. \& Neuvonen, M. (2006) Recreational Wild Berry Picking in Finland-Reflection of a Rural Lifestyle. Society and Natural Resources 19(4) 285-304.

Pryor, F. L. (1982) The Plantation Economy as an Economic System. Journal of Comparative Economics 6 288-317.

Puig de la Bellacasa, M. (2017) Matters of Care: Speculative Ethics in More Than Human Worlds. University of Minnesota Press, Minneapolis.

Rantanen, P. \& Valkonen, J. (2011). Ulkomaalaiset metsämarjanpoimijat Suomessa. https://um.fi/ documents/35732/48132/tutkimus_ulkomaalaiset_mets\%C3\%A4marjanpoimijat_pdf.pdf

Ristioja, A. (2017) Luonnontuoteala. Työ- ja elinkeinoministeriön toimialaraport http://julkaisut.valtioneuvosto. fi/bitstream/handle/10024/79898/Luonnontuoteala_2017.pdf

Roelvink, G. (2015) Performing posthumanist economies. Teoksessa Roelvink, G., St. Martin, K. \& GibsonGraham, J. K. (toim.) Making Other Worlds Possible: Performing Diverse Economies., 225-243. University of Minnesota Press, Minneapolis.

Roelvink, G., St. Martin, K. \& Gibson-Graham, J. K. (toim.) (2015) Making Other Worlds Possible: Performing Diverse Economies. University of Minnesota Press, Minneapolis.

Ruokavirasto (2019) Marsi 2018. Luonnonmarjojen ja -sienten kauppaantulomäärät vuonna 2018. Ruokavirasto 3/2019. https://www.ruokavirasto.fi/globalassets/viljelijat/tuet-ja-rahoitus/marsi-2018-raportti.pdf

Saastamoinen, O. (2012) Metsä ja puut ihmisten arjessa. Tieteessä tapabtun 2/2012 15-19.

Saastamoinen, O. \& Vaara, M. (2009) Small-Scale Forest Related Activities in the Everyday Life of the Finns: Results of Time-Budget Studies. Small-scale Forestry 8 425-445. https://doi.org/10.1007/s11842-009-9093-3

Sabatini, F. M., Burrascano, S., Keeton, W. S., Levers, C., Lindner, M., Pötzschner, F., Verkerk, P. J., Bauhus, J., Buchwald, E., Chaskovsky, O., Debaive, N., Horváth, F., Garbarino, M., Grigoriadis, N., Lombardi, F., Marques Duarte, I., Meyer, P., Midteng, R., Mikac, S., Mikoláš, M., Motta, R., Mozgeris, G., Nunes, L., Panayotov, M., Ódor, P., Ruete, A., Simovski, B., Stillhard, J., Svoboda, M., Szwagrzyk, J., Tikkanen, O.-P., Volosyanchuk, R., Vrska, T., Zlatanov, T., Kuemmerle, T. (2018) Where are Europe's last primary forests? Diversity and Distributions 24(10) 1426-1439.

Safri, M. \& Graham, J. (2015) International Migration and the Global Household. Performing Diverse Economies on the World Stage. Teoksessa Roelvink, G., St. Martin, K. \& Gibson-Graham, J. K. (toim.) Making Other Worlds Possible: Performing Diverse Economies, 244-268. University of Minnesota Press, Minneapolis.

Saksa, T. (2019) Maanmuokkauksen historia ja kehitys. Teoksessa Laine, T., Luoranen, J. \& Ilvesniemi, H. (toim.) Metsämaan muokkaus. Kirjallisuuskatsaus maanmuokkauksen vaikutuksista metsänuudistamiseen, vesistöibin sekä ekologiseen ja sosiaaliseen kestäyyteen, 8-9. Luonnonvara- ja biotalouden tutkimus 58/2019. Luonnonvarakeskus, Helsinki.

Saksa, T. Luoranen, J. \& Uotila, K. (2014). Metsänuudistaminen. Teoksessa Rantala, S. (toim.) Metsäkoulu, 79-114. Metsäkustannus, Helsinki. 8. p.

Salin, M. (2018) Metsä - iloa ja byötyä kaikille. UPM 16.10.2018<https://www.upm.com/fi/ajankohtaista/ artikkelit/2018/10/metsa-iloa-ja-hyotya-kaikille/>. 15.6.2020.

Salo K. (2019) The structure of macrofungal assemblages in boreal forests, with particular reference to the effect of fire on 
Basidiomycota and Ascomycota. Academic dissertation. School of Forest Sciences, Faculty of Science and Forestry, University of Eastern Finland. https://doi.org/10.14214/df.279

Salo, K. \& Turtiainen, M. (2015) Kauppayrtit, keruu ja käyttö. Teoksessa Salo, K. (toim.) Metsä. Monikäyttö ja ekosysteemipalvelut, 180-183. Luonnonvarakeskus, Helsinki.

Sedgwick, E. K. (2003) Touching, Feeling: Affect, Pedagogy, Performativity. Duke University Press, Durham.

Sievänen, T. \& Neuvonen, M. (2011) Luonnon virkistyskäyttö 2010. Metlan työraportteja 212. Metsäntutkimuslaitos, Vantaa. http://www.metla.fi/julkaisut/workingpapers/2011/mwp212.htm

Staddon, C. (2009) Towards a critical political ecology of human-forest interactions: collecting herbs and mushrooms in a Bulgarian locality. Transactions of the Institute of British Geographers 34(2) 161-176.

Suomen virallinen tilasto, SVT (2020) Vapaa-ajan osallistuminen. Tilastokeskus, Helsinki. <http://www.stat.fi/ til/vpa/index.html>. 3.6.2020.

Säynäjäkangas, J. (2019) Nähdä metsä puilta: Yhteismitallisuus ympäristökysymyksenä. Tiede \& Edistys 2/2019 87-119.

Säynäjäkangas, J. \& Kellokumpu, V. (2020) Biotaloutta vai kuitupunkapitalismia? Politiikasta. 14.10 .2020 <https:// politiikasta.fi/biotaloutta-vai-kuitupuukapitalismia>. 20.10.2020.

Tahvanainen, V., Miina, J. \& Kurttila, M. (2019) Climatic and Economic Factors Affecting the Annual Supply of Wild Edible Mushrooms and Berries in Finland. Forests 10(5) 385. http://dx.doi.org/10.3390/f10050385

Takala, T., Lehtinen, A., Tanskanen, M., Hujala, T. \& Tikkanen, J. (2019) The rise of multi-objective forestry paradigm in the Finnish print media. Forest Policy and Economics 106 101973. https://doi.org/10.1016/j. forpol.2019.101973

Thompson, E. T. (2010) The Plantation. (toim.) Mintz, S. W. \& Baca, G. University of South Carolina Press, Columbia.

Tsing, A. L. (2015) The Mushroom at the End of the World: On the Possibility of Life in Capitalist Ruins. Princeton University Press, Princeton.

Turtiainen, M., Saastamoinen, O., Kangas, K. \& Vaara, M. (2012) Picking of wild edible mushrooms in Finland in 1997-1999 and 2011. Silva Fennica 46(4) 569-581. http://dx.doi.org/10.14214/sf.911

Vaara, M., Saastamoinen, O \& Turtiainen, M. (2013) Changes in wild berry picking in Finland between 1997 and 2011. Scandinavian Journal of Forest Research 28(6) 586-595. http://dx.doi.org/10.1080/02827581.20 13.786123

Vehviläinen, M. (2014) Syömisen politiikka arjessa. Teoksessa Irni, S., Meskus, M. \& Oikkonen, V. (toim.) Muokattu elämä: teknotiede, sukupuoli ja materiaalisuus, 305-341. Vastapaino, Tampere.

Verohallinto (2020) Luonnontuotetulojen verotus. Diaarinumero VH/2301/00.01.00/2020. Annettu 16.6.2020. <https://www.vero.fi/syventavat-vero-ohjeet/ohje-hakusivu/48538/luonnontuotetulojen-verotus>. 22.7.2020.

Vuolle, P. \& Oittinen, A. (1994) Jokamiehenoikeus: perinteistä nykypäivää: tutkimus jokamiehenoikeuden kulttuurisesta, oikeudellisesta ja luontoliikunnallisesta merkityksestä. Liikunnan ja kansanterveyden julkaisuja 92. Liikunnan ja kansanterveyden edistämissäätiö, Jyväskylä.

Waskey, A. J. (2011) Plantation. Teoksessa Mulvaney, D. (toim.) Green Food: An A to Z Guide, 355-357. SAGE Publications, Thousand Oaks.

YLE (2020) Metsässä on sama ongelma kuin marjatiloilla - kroaatit istuttavat kunsimetsää, koska kausityö ei kiinnosta suomalaisia. 20.5.2020<https://yle.fi/uutiset/3-11360603>. 20.5.2020.

YLE (2016) Analyysi: Yli miljoonan hehtaarin maaomistus ulkomailla - onko Suomi nykyajan sürtomaaisäntä? 29.11.2016 $<$ https://yle.fi/uutiset/3-9319223>. 20.10.2020.

Ylitalo, M. (2008) Luontoisetuina gourmet-tason makuelämyksiä - Suuria alueittaisia eroja luonnon antimien keräämisessä. Kuntapuntari 1/2008.11.8.2008. < https://www.stat.fi/artikkelit/2008/art_2008-05-08_002. html>. 30.11.2018.

Äijälä, O., Koistinen, A., Sved, J., Vanhatalo, K. \& Väisänen, P. (toim.) (2019) Metsänhoidon suositukset. Tapion julkaisuja. https://tapio.fi/wp-content/uploads/2020/09/Metsanhoidon_suositukset_Tapio_2019.pdf 